\title{
Expression and function of G-protein-coupled receptors in the male reproductive tract
}

\author{
MARIA CHRISTINA W. AVELlaR, MARIA FATIMA M. LÁZARI and CATARINA S. PORTO \\ Setor de Endocrinologia Experimental, Departamento de Farmacologia, Universidade Federal de São Paulo \\ Escola Paulista de Medicina, Rua Três de Maio, 100, $4^{\circ}$ andar, Vila Clementino, 04044-020 São Paulo, SP, Brasil \\ Manuscript received on July 6, 2008; accepted for publication on August 14, 2008; \\ presented by LUIZ R. TRAVASSOS
}

\begin{abstract}
This review focuses on the expression and function of muscarinic acetylcholine receptors (mAChRs), $\alpha_{1}$-adrenoceptors and relaxin receptors in the male reproductive tract. The localization and differential expression of mAChR and $\alpha_{1^{-}}$ adrenoceptor subtypes in specific compartments of the efferent ductules, epididymis, vas deferens, seminal vesicle and prostate of various species indicate a role for these receptors in the modulation of luminal fluid composition and smooth muscle contraction, including effects on male fertility. Furthermore, the activation of mAChRs induces transactivation of the epidermal growth factor receptor (EGFR) and the Sertoli cell proliferation. The relaxin receptors are present in the testis, RXFP1 in elongated spermatids and Sertoli cells from rat, and RXFP2 in Leydig and germ cells from rat and human, suggesting a role for these receptors in the spermatogenic process. The localization of both receptors in the apical portion of epithelial cells and smooth muscle layers of the vas deferens suggests an involvement of these receptors in the contraction and regulation of secretion.
\end{abstract}

Key words: muscarinic acetylcholine receptors, $\alpha_{1}$-adrenoceptors, relaxin receptors, male reproductive tract.

\section{INTRODUCTION}

G-protein-coupled receptors (GPCRs) play different roles in autocrine and neuronal systems and are important in the physiology and pathophysiology of various organs. The activation of these receptors may affect cell proliferation, differentiation, growth and other functions in the male reproductive tract organs. This review focuses on the expression and function of muscarinic acetylcholine receptors (mAChRs), $\alpha_{1}$-adrenoceptors and relaxin receptors in the male reproductive tract Firstly, the differential expression of mAChR subtypes $\left(\mathrm{M}_{1}, \mathrm{M}_{2}, \mathrm{M}_{3}, \mathrm{M}_{4}\right.$ and $\left.\mathrm{M}_{5}\right)$ in Sertoli cells, efferent ductules, epididymis, seminal vesicle and their pharmaco-

In commemoration of the $75^{\text {th }}$ anniversary of

Escola Paulista de Medicina / Universidade Federal de São Paulo.

All authors contributed equally to this work.

Correspondence to: Dr. Catarina Segreti Porto

E-mail: csporto@unifesp.br logical characteristics, intracellular signaling and possible interaction with growth factors are presented. Secondly, aspects of the genomic organization, structure, tissue distribution in the male reproductive tract and pharmacological characteristics and function of the different $\alpha_{1}$-adrenoceptors subtypes $\left(\alpha_{1 \mathrm{~A}^{-}}, \alpha_{1 \mathrm{~B}^{-}}\right.$and $\alpha_{1 \mathrm{D}^{-} \text {-adreno- }}$ ceptors) are reviewed. Lastly, the function and distribution in the male reproductive organs of the recently discovered relaxin receptors are discussed.

\section{MUSCARINIC ACETYLCHOLINE RECEPTORS: SUBTYPES, EXPRESSION AND CELLULAR SIGNALING MECHANISMS IN THE MALE REPRODUCTIVE TRACT}

The cellular actions of acetylcholine (ACh) are mediated by two structurally different families of membranebound proteins: the nicotinic receptors and muscarinic acetylcholine receptors (mAChRs) (for review see Hul- 
me et al. 1990, Caulfield and Birdsall 1998, Wess 2004, Eglen 2006). mAChRs are class I heptahelical G-protein-coupled receptors (GPCRs) and comprise five distinct subtypes $\left(\mathrm{M}_{1}\right.$ to $\left.\mathrm{M}_{5}\right)$ encoded by different intronless genes (Kubo et al. 1986). The similarity in ligandbinding sites across the five subtypes explains why the development of subtype-selective ligands has been difficult (Hulme et al. 1990). In addition to agonist-binding sites, mAChRs possess allosteric sites that bind modulators of receptor activation. These allosteric sites differ from the agonist-binding site, and they are receptorsubtype specific, a characteristic especially favorable for the design of subtype-selective modulators (Birdsall and Lazareno 2005).

The coupling of mAChRs to their cellular effector systems is mediated via heterotrimeric guanine nucleotide-binding proteins (G-proteins) (for review see Lanzafame et al. 2003). $M_{1}, M_{3}$ and $M_{5}$ mAChRs preferentially couple with $\mathrm{G}_{\mathrm{q} / 11}$, mobilize phosphoinositides to generate inositol 1,4,5-triphosphate (IP3) and 1,2-diacylglycerol (DAG) via activation of phosphoinositidespecific phospholipase $\mathrm{C} \beta$ ( $\mathrm{PLC} \beta$ ), leading to an increase in intracellular $\mathrm{Ca}^{2+}$ and protein kinase $\mathrm{C}$ (PKC) activity. $\mathrm{M}_{2}$ and $\mathrm{M}_{4} \mathrm{mAChRs}$ preferentially couple with $\mathrm{G}_{\mathrm{i} / \mathrm{o}}$ and inhibit elevated adenylylcyclase activity. $\mathrm{M}_{2}$ mAChRs, via $\mathrm{G} \beta \gamma$, can also activate $\operatorname{PLC} \beta$. Furthermore, mAChRs have also been shown to regulate other signaling pathways. Hence, both $\mathrm{G} \alpha_{\mathrm{q} / 11^{-}}$and $\mathrm{G} \alpha_{\mathrm{i} / \mathrm{o}^{-}}$ coupled with mAChRs may exert effects through activation of small GTPases, such as Rho and Ras, and downstream effectors, such as phosphoinositide-3 kinases (PI3 kinases), non-receptor tyrosine kinases, and mitogenactivated protein kinases (MAP kinases) (for review see Lanzafame et al. 2003, van Koppen and Kaiser 2003). The latter signaling pathway seems to play a major role in the autocrine functions of mAChRs in terms of the control of cell growth or proliferation, secretion by epithelial cells, and apoptosis (for review see Eglen 2006).

The importance of mAChRs for fertility has been revealed by the demonstration that $\mathrm{mAChR}$ antagonists impair fertility in male rats (Ban et al. 2002, Sato et al. 2005), but the underlying mechanisms that cause this infertility remain unclear. The study of the expression, localization and function of mAChR subtypes in the male reproductive tract is essential to understand the role of the cholinergic nervous system in male fertility.

In an attempt to clarify the pathophysiology of idiopathic male infertility and to develop new methods for male contraception, researchers have focused on local regulators of intratesticular events (Huleihel and Lunenfeld 2004, Walker and Cheng 2005, Yan et al. 2007) and Sertoli cells play an important role in this process (Skinner 2005). Studies from our laboratory have shown the presence of $\mathrm{M}_{1}$ to $\mathrm{M}_{5} \mathrm{mAChRs}$ (mRNA and protein) in primary culture of Sertoli cells from 15day and 30-day old rats (Borges et al. 2001, Lucas et al. 2008). mAChRs have been localized in plasma membrane, cytoplasmic organelles, perinuclear region and nuclei in cultured Sertoli cells from 15-day old rats by using immunofluorescence studies and confocal laser scanning microscopy. $\mathrm{M}_{1}, \mathrm{M}_{3}$ and $\mathrm{M}_{5} \mathrm{mAChR}$ subtypes are mainly localized in the cell nuclei, with a weak to moderate staining visible in the plasma membrane and perinuclear region of Sertoli cells. On the other hand, $\mathrm{M}_{2}$ and $\mathrm{M}_{4} \mathrm{mAChR}$ subtypes are predominantly localized in the plasma membrane, with some staining in the perinuclear region (Lucas et al. 2008). Although the functional significance of $\mathrm{mAChRs}$ in the plasma membrane is well established, their presence in subcellular regions has been observed in several cell types (Bernard et al. 1999, 2003, Salamanca et al. 2005). The number of receptors at the plasma membrane is frequently regulated to modulate cell responses upon stimulation. Therefore, the intracellular pool of mAChRs may represent both newly synthesized and recycled stores of receptors in amounts that vary with the balance between the rate of synthesis and the shedding and desensitization processes. The neurochemical environment may contribute to the control of the abundance and availability of cell surface receptors and, consequently, to the control of neuronal sensitivity to neurotransmitters or $\mathrm{mAChR}$ agonists, by regulating their delivery from the endoplasmic reticulum and Golgi complex (Bernard et al. 1999, 2003).

The presence of mAChRs gives support to the idea that the cholinergic neurotransmission may have a physiological role in Sertoli cells. In fact, $\mathrm{mAChR}$ agonist inhibits FSH-induced cyclic AMP accumulation in 
cultured Sertoli cells from immature hamster (Davenport and Heindel 1987) and induces phosphoinositide hydrolysis and time-dependent stimulation of the activator protein-1 DNA-binding activity in cultured Sertoli cells from 30-day old rats (Borges et al. 2001). The activation of mAChRs also rapidly stimulates [methyl$\left.{ }^{3} \mathrm{H}\right]$ thymidine incorporation in cultured Sertoli cells obtained from 8-day and 15-day old rats, in a concentrationdependent and time-dependent manner, suggesting an induction of DNA synthesis and/or DNA repair (Lucas et al. 2004). Furthermore, the activation of mAChRs induces transactivation of the epidermal growth factor receptor (EGFR) through $\beta \gamma$-subunits of $\mathrm{G}$ proteins that promote Src-mediated metalloprotease-dependent cleavage and release of EGFR ligands from the cell surface and binding to EGFR and activation of extracellular signal-regulated kinases (Erk)1/2 in Sertoli cells from 15-day old rats. PLC $\beta$ and intracellular $\mathrm{Ca}^{2+}$ mobilization, but not PKC, are involved in the Erk1/2 phosphorylation induced by $\mathrm{mAChRs}$ in Sertoli cells (Lucas et al. 2008). The transactivation of EGFR by the agonist$\mathrm{mAChR}$ complex is also involved in the Sertoli cell proliferation (Lucas et al. 2008). The characterization of the signaling pathways regulated by the agonist-mAChR complex in Sertoli cells is an important step to understand how this complex may support spermatogenesis. It is important that future studies focus on components of the MAP kinase pathway, such as transcription factors, regulatory kinases and phosphatases, and the involvement of other signaling pathways that could be mediated by mAChRs, such as activation of PI3 kinase and phospholipase $\mathrm{A}_{2}\left(\mathrm{PLA}_{2}\right)$, as they may represent additional mechanisms for the regulation of protein secretion and cell junction dynamics in the testis.

In the rat epididymis, studies from our laboratory have shown the presence of mRNA for $M_{1}, M_{2}$ and $M_{3}$ mAChRs in the caput and cauda region (Maróstica et al. 2001, 2005). The levels of mRNA for $M_{2}$ subtype are higher in the cauda than in the caput of the epididymis. Low levels of $M_{1}$ mRNA are present in the caput and cauda of the epididymis, and low levels of $\mathrm{M}_{3}$ mRNA are found in the caput region (Maróstica et al. 2005). mRNA for $M_{1}, M_{2}$ and $M_{3}$ mAChRs is also present in efferent ductules (Siu et al. 2006).
Immunolocalization of mAChR subtypes in rat efferent ductules and epididymis has indicated a variable degree of immunostaining for each mAChR subtype in a cell-type and tissue-specific pattern (Siu et al. 2006). $\mathrm{M}_{1} \mathrm{mAChR}$ is detected in the epithelium of the efferent ductules, while $\mathrm{M}_{2}$ and $\mathrm{M}_{3} \mathrm{mAChRs}$ are observed in the apical region of the ciliated cells of the efferent ductules. Apical and narrow cells of the initial segment of the epididymis show a distinct staining for $M_{1}$ subtype, whereas supranuclear localization is noted in principal cells of the caput of the epididymis. In addition, staining for $\mathrm{M}_{1}$ and $\mathrm{M}_{2} \mathrm{mAChRs}$ is visible in the apical membrane of some epithelial cells of the cauda of the epididymis (Siu et al. 2006). These findings suggest a relationship between $\mathrm{mAChRs}$ activation and secretory processes. In fact, the activation of mAChRs stimulates chloride secretion in cultured rat epididymal epithelium (Du et al. 2006), and increases $\left[{ }^{35} \mathrm{~S}\right]$-Methionine incorporation in proteins secreted by rat efferent ductules and in secreted and tissular proteins of the caput of the epididymis. These effects were abolished by atropine, a nonselective $\mathrm{mAChR}$ antagonist (E.R. Siu et al., unpublished data). Immunoreactivity for $\mathrm{M}_{3} \mathrm{mAChR}$ is detected in the peritubular smooth muscle of the efferent ductules and along the different epididymal regions, with a strong reaction in the proximal and distal cauda, suggesting that this receptor subtype may play a role in smooth muscle contraction (Siu et al. 2006). Indeed, hexahydro-sila-difenidol (HHSiD), a $\mathrm{M}_{3} / \mathrm{M}_{1}$ selective mAChR antagonist, is able to abolish contractions induced by carbachol, a stable analog of ACh, indicating the involvement of $\mathrm{M}_{3} \mathrm{mAChRs}$ in the epididymal tubule contraction (Siu et al. 2006). Cell-specific expression of the mAChR subtypes in the efferent ductules and epididymis suggests the role of these receptors in the modulation of smooth muscle contraction and the composition of the luminal fluid, which is essential for post-testicular maturation of spermatozoa.

In the dog vas deferens, binding studies have shown the presence of mAChRs. The prostatic region expresses a greater amount of mAChRs than the intermediate or epididymal regions (Kondo et al. 1994). mAChRs have been also described in the human vas deferens (Miranda et al. 1992). In the guinea-pig vas deferens, $M_{3} m A C h R$ 
potentiates $\mathrm{P}_{2 \mathrm{X}}$ receptor-mediated contractions, but not adrenoceptor-mediated contractions (Iram and Hoyle 2005). In rabbit vas deferens, prejunctional $\mathrm{M}_{1} \mathrm{mAChRs}$ inhibit the release of endogenous noradrenaline (Grimm et al. 1994) and the contractile response of vas deferens (Shannon et al. 1993). The presence of mRNA or protein for $\mathrm{M}_{1}, \mathrm{M}_{2}$ and $\mathrm{M}_{3} \mathrm{mAChRs}$ has also been shown in rat vas deferens (Miranda et al. 1994, 1995), and $\mathrm{M}_{1}$ and $\mathrm{M}_{2} \mathrm{mAChRs}$ are involved in the contraction of the epididymal region of rat vas deferens (Doggrell 1986). The cell- and region-specific expression of mAChR subtypes in vas deferens and the role of each subtype in different species remain to be explored.

The presence of mRNA for the five mAChRs has been shown in the rat seminal vesicle (Hamamura et al. 2006). $M_{3} m A C h R$ is predominantly involved in the contraction of the seminal vesicle in guinea-pigs (Eglen et al. 1992) and rats (Hamamura et al. 2006). Immunohistochemical studies revealed the presence of $\mathrm{M}_{2}$ and $\mathrm{M}_{3}$ mAChRs in the smooth muscle layers of the rat seminal vesicle (Hamamura et al. 2006). $\mathrm{M}_{2}$ and $\mathrm{M}_{3}$ $\mathrm{mAChRs}$ may also be involved in protein secretion since they are present in epithelial cells of the rat seminal vesicle (Hamamura et al. 2006). Other evidence that supports this suggestion is that mAChR agonists stimulate protein secretion in cultured epithelial cells of the rat seminal vesicle (Kinghorn et al. 1987), alkaline phosphatase secretion and phospholipid synthesis in the guinea-pig seminal vesicle (Lockwood and WilliamsAshman 1971), and fructose release from epithelial cells of guinea-pig seminal vesicle via nitric oxide production (Ehrén et al. 1997). Apart from the effects on protein secretion, mAChRs are also involved in mitogenic effects in cultured epithelial cells from the rat seminal vesicle (Kinghorn et al. 1987). Recent studies from our laboratory have shown that the mechanism by which agonist-mAChR acts in seminal vesicle involves the transactivation of the EGFR through $\mathrm{G} \beta \gamma$-subunits proteins that promote Src-mediated metalloprotease-dependent cleavage and release of EGFR ligands from the cell surface and binding to EGFR and Erk1/2 activation. Furthermore, PLC, intracellular $\mathrm{Ca}^{2+}$ mobilization and PKC are also involved in the Erk1/2 phosphorylation induced by the activation of mAChRs (M. Hamamura et al., unpublished data). Further studies are necessary to understand the role of the agonist-mAChR-Erk1/2 in the proliferation, differentiation and secretion in the seminal vesicle and, consequently, the impact of the cholinergic nervous system to male fertility.

The presence of $\mathrm{M}_{2} \mathrm{mAChR}$ in the rat prostate has been shown by immunoprecipitation studies (Ruggieri et al. 1995). On the other hand, binding studies with selective antagonists suggested the presence of $\mathrm{M}_{3}$ mAChRs (Lau and Pennefather 1998), and immunostaining confirmed the presence of $\mathrm{M}_{3} \mathrm{mAChR}$ in the outer muscle layer surrounding the prostatic acini (Nadelhaft 2003). In fact, $\mathrm{mAChR}$ agonist-induced contractions of the ventral lobe of the rat prostate seem to be mediated by $\mathrm{M}_{3} \mathrm{mAChR}$ (Lau and Pennefather 1998, Ventura et al. 2002). The expression of $m A C h R$ subtypes varies among the different lobes of the rat prostate; immunohistochemistry combined with RT-PCR analysis suggests that $\mathrm{M}_{3} \mathrm{mAChRs}$ are predominantly expressed in the ventral lobe and $\mathrm{M}_{2} \mathrm{mAChRs}$ in the dorsolateral lobe (Pontari et al. 1998). The activation of mAChRs in rat prostate gland induces glandular secretion (Wang et al. 1991) and increases $\mathrm{Ca}^{2+}$ with concomitant activation of $\mathrm{K}^{+}$and $\mathrm{Cl}^{-}$channels, which are essential for fluid secretion (Kim et al. 2005).

$\mathrm{M}_{2}$ mAChR mRNA (Obara et al. 2000) and protein (Yazawa et al. 1994) are detected in cultured prostate smooth muscle cells from human patients with benign prostatic hypertrophy. Additionally, $\mathrm{M}_{1} \mathrm{mAChRs}$ are present on glandular epithelial cells from these patients (Ruggieri et al. 1995) and $\mathrm{M}_{3} \mathrm{mAChR}$ is present in the LNCaP prostatic cancer cell line (Rayford et al. 1997). Other studies in prostate cell lines have revealed controversial findings. LNCaP cells, as well as DU145 cells, express approximately equal amounts of $\mathrm{M}_{1}$ and $\mathrm{M}_{3} \mathrm{mAChRs,}$ whereas PC3 cells express only $\mathrm{M}_{3}$ mAChRs (Luthin et al. 1997), and mAChR agonist increases phosphatidylinositol turnover in $\mathrm{PC} 3$, but not in DU145 or LNCaP cell lines.

A high expression of $\mathrm{M}_{3} \mathrm{mAChRs}$ has been correlated with differentiation of the human prostatic epithelium (Blanco and Robinson 2004). Normal prostate cell lines fail to proliferate or increase Erk activity upon $\mathrm{mAChR}$ agonist stimulation, although an increase is ob- 
served in Jun N-terminal kinase activity (Ruggieri et al. 1995, Luthin et al. 1997). On the other hand, mAChR agonist induces growth of prostate epithelial cells and an increase in Erk activity in several prostate cancer cell lines (Rayford et al. 1997, Luthin et al. 1997), while in PC3 prostate carcinoma cells, mAChR activation induces transactivation of EGFR (Prenzel et al. 1999). Moreover, several studies suggest a direct or indirect role for the Erk1/2 signaling pathway in the development of prostate cancer (Papatsoris et al. 2007), but reports of Erk1/2 activation in prostate cancer have been controversial. Further characterization is necessary to understand the role of the agonist-mAChR complex and the intracellular signaling pathways involved in secretion, proliferation and differentiation in the prostate.

Multiple factors may be involved in the regulation of mAChRs. Briefly, studies have pointed out the importance of a physiological balance between androgen and testicular factors in the regulation of mAChRs in the rat epididymis (Maróstica et al. 2005). Moreover, androgen also modulates mAChRs present in the rat vas deferens (Longhurst and Brotcke 1989) and prostate (Shapiro et al. 1985).

\section{$\alpha_{1}$-ADRENOCEPTORS: SUBTYPES AND EXPRESSION IN THE MALE REPRODUCTIVE TRACT}

The natural adrenergic amines, adrenaline and noradrenaline, are among the most important regulators of physiological functions and biochemical processes in the organism, through their release by adrenal medulla and related chromaffin structures and the sympathetic nervous system (for review see Docherty 2002, Jackson and Cunnane 2001, Eisenhofer 2001). With adrenergic nerve stimulation, noradrenaline is released from the nerve terminal. The action of this neurotransmitter can be mediated on the target cell by three subfamilies of Gprotein-coupled receptors ( $\alpha_{1}, \alpha_{2}$ and $\beta$-adrenoceptors), each of them comprising different receptor subtypes which are products of separate genes: $\alpha_{1}\left(\alpha_{1 \mathrm{~A}^{-}}, \alpha_{1 \mathrm{~B}^{-}}\right.$ and $\alpha_{1 \mathrm{D}^{-}}$adrenoceptors); $\alpha_{2}\left(\alpha_{2 \mathrm{~A}^{-}}, \alpha_{2 \mathrm{~B}^{-}}\right.$and $\alpha_{2 \mathrm{C}^{-}}$-adrenoceptors) and $\beta$ ( $\beta_{1-}, \beta_{2}$ - and $\beta_{3}$-adrenoceptors). They play important roles in the regulation of diverse physiological systems throughout the body and are involved in the treatment and control of a variety of cardiovascular, respiratory, urogenital and mental disorders (for re- views see Langer 1999, Ruffolo and Hieble 1999, Zhong and Minneman 1999, Brodde and Leineweber 2004). In this review, aspects of the genomic organization, structure, tissue distribution in the male reproductive tract and function of $\alpha_{1}$-adrenoceptors are presented.

$\alpha_{1}$-adrenoceptor subtypes $\left(\alpha_{1 \mathrm{~A}^{-}}, \alpha_{1 \mathrm{~B}^{-}}\right.$and $\alpha_{1 \mathrm{D}^{-}}$ adrenoceptor) are encoded by three separate genes (denoted $A D R A 1 A, A D R A 1 B$ and $A D R A 1 D$ ) as single-chain protein products (Morrow and Creese 1986, Schwinn et al. 1990, Ramarao et al. 1992, Yang-Feng et al. 1990, 1994, Hieble et al. 1995, Piascik et al. 1995, Docherty 1998). All $\alpha_{1}$-adrenoceptor subtypes contain:

1) a common overall structure with seven hydrophobic transmembrane (TM1-TM7) helices interconnected by hydrophilic sections composed of three intracellular and three extracellular loops;

2) an extracellular N-termini which contains consensus sites for N-linked glycosylation (Sawutz et al. 1987);

3) an intracellular C-termini which contains consensus sites for phosphorylation by protein kinases (Leeb-Lundberg et al. 1985, Lefkowitz 1998, Lefkowitz et al. 1998, Vázquez-Prado et al. 2000) and interaction with regulatory proteins (Hirasawa et al. 2001, Pupo and Minneman 2003, Diviani et al. 2003); and

4) second and third intracellular loops that are involved in the coupling with heterotrimeric $G$ proteins (Hieble et al. 1995, Lefkowitz and Caron 1988, Graham et al. 1996).

Functional studies and computational molecular modeling also indicate amino acids located mainly on transmembrane domains TM3, TM5 and TM6 with important role in the binding of the endogenous catecholamines to $\alpha_{1}$-adrenoceptors (Piascik and Perez 2001, Porter et al. 1996, Hwa and Perez 1996, Chen et al. 1999, Waugh et al. 2000, Hwa et al. 1995, 1996, Pedretti et al. 2004).

All three $\alpha_{1}$-adrenoceptor genes present a genomic structure of at least two exons separated by a large intron ranging from 7.2-93 $\mathrm{kbp}$ in different species (Yasuoka et al. 1996, Perez et al. 1994, Ramarao et al. 1992). The first exon contains the nucleotide sequence codeing for the N-terminus through the transmembrane 
domain TM6 of the receptor, while the second exon encodes the third extracellular loop, transmembrane domain TM7 and all (or most) of the C-terminal region (Ramarao et al. 1992, Esbenshade et al. 1995). Additional exons are known to be present in the ADRA1A gene in human (Hirasawa et al. 1995, Chang et al. 1998, Cogé et al. 1999, Patrão et al. 2008), rabbit (Suzuki et al. 2000), guinea-pig (González-Espinosa et al. 2001) and rhesus monkey (Patrão et al. 2008), whose alternative use leads to several transcript variants by splicing mechanisms. In humans, at least eleven different ADRA1A splice variants have been reported (Hawrylyshyn et al. 2004). A summary of the nomenclature of the genes, transcripts and their corresponding isoforms for all these splicing variants can be found in Patrão et al. (2008). Four of these variants, differing in length and sequence of the C-terminal region, are functional proteins with pharmacological profile and ability to mediate effects induced by norepinephrine similar to the classical $\alpha_{1 \mathrm{~A}}$-adrenoceptor (wild type, ADRA1A_i1) (Hirasawa et al. 1995, Chang et al. 1998, Cogé et al. 1999, Hawrylyshyn et al. 2004). They present, however, differences in G-protein coupling specificity and down-regulation mechanisms are suggested among these splice variants (Hirasawa et al. 1995, Chang et al. 1998, Price et al. 2002). The other seven human splice variants, differing in length and sequence in the C-terminal region, code for non-functional truncated isoforms that lack TM7 and, for this reason, are incapable of ligand binding and activating signal transduction (Chang et al. 1998, Cogé et al. 1999, Hawrylyshyn et al. 2004). Differences in the relative abundance, cellular localization and possible functions for these ADRA1A gene splice variants have been suggested (Hirasawa et al. 1995, Cogé et al. 1999, Schwinn and Kwatra 1998, Ramsay et al. 2004, Patrão et al. 2008). Functional and truncated ADRA1A splice variants are differentially expressed in different tissues of the male reproductive tract of humans and rhesus monkeys (testis, epididymis, prostate and seminal vesicle), raising the question about their relevance in physiological and pathological events in these tissues (Patrão et al. 2008). No ADRA1A splice variants have been detected in rodents, and the physiological significance of these splices variants in humans and other species, however, remains to be determined.

All three $\alpha_{1}$-adrenoceptor subtypes show similar potencies and intrinsic efficacies to endogenous ligands released from the sympathetic fibers (noradrenaline and adrenaline) and high affinity to the nonspecific $\alpha_{1}$ adrenoceptor antagonist prazosin (Hieble and Ruffolo 1996). A fourth subtype has been proposed based on its lower affinity to prazosin. The receptor subtype, designated $\alpha_{1 \mathrm{~L}}$-adrenoceptor, is probably not a disctint receptor but rather a low-affinity state of the $\alpha_{1 \mathrm{~A}}$-adrenoceptor (Ford et al. 1997, Daniels et al. 1999) and has been reported to be involved in smooth muscle contraction of human, rabbit and dog lower urinary tract tissues (Muramatsu et al. 1994, Ford et al. 1996, Testa et al. 1996, Fukasawa et al. 1998) with an important role in the treatment of stress urinary incontinence (Bishop 2007). The antagonists 5-methyl urapidil, WB 4101 and niguldipine show higher affinity for $\alpha_{1 \mathrm{~A}}$-adrenoceptors, while BMY 7378 recognizes preferentially $\alpha_{1 \mathrm{D}}$-adrenoceptors (Deng et al. 1996, Saussy et al. 1996, Yang et al. 1997). The alkylating agent chloroethylclonidine is an irreversible antagonist that mostly inactivates both $\alpha_{1 \mathrm{~B}}$ and $\alpha_{1 \mathrm{D}}$-adrenoceptors (Laz et al. 1994, Hieble et al. 1995, Xiao and Jeffries 1998).

$\alpha_{1}$-adrenoceptors are preferentially coupled with $\mathrm{G}_{\mathrm{q} / 11}$ protein and activate phospholipase $\mathrm{C} \beta$ to form DAG and $\mathrm{IP}_{3}$, inducing consequent increase in cytosolic concentration of $\mathrm{Ca}^{2+}$ and PKC, which in turn phosphorylates several substrates (Zhong and Minneman 1999, Hein and Michel 2007). The relative coupling efficiencies to second messenger formation differs depending on the receptor subtype $\left(\alpha_{1 \mathrm{~A}}>\alpha_{1 \mathrm{~B}}>\alpha_{1 \mathrm{D}}\right.$; Theroux et al. 1996, Zhong et al. 2001). There are also evidences that, depending on the cell or tissue which were analyzed, $\alpha_{1}$-adrenoceptors can also couple with different $G$ protein $\left(G_{i}, G_{s}\right.$ and $G_{h}$; Horie et al. 1995, Hu and Nattel 1995, Chen et al. 1996, Nakaoka et al. 1994, Shinoura et al. 2002) activating different signaling pathways to modulate cellular function (Michelotti et al. 2000, Wier and Morgan 2003) and possibly modulating L-type calcium, sodium and cation channels from TRP family (Yoshinaga et al. 1999, Murray et al. 1997, Thebault et al. 2005). 
The complexity of the events involved in $\alpha_{1}$-adrenoceptor activation is further demonstrated by the fact that several interacting proteins can allow differential signalling, regulation and subcellular localization for each subtype $\alpha_{1}$-adrenoceptors (Hu and Nattel 1995, Chen et al. 1996, Wang et al. 2005, Xu et al. 1999). Also, there are evidences that $\alpha_{1 \mathrm{~A}^{-}}, \alpha_{1 \mathrm{~B}^{-}}$and $\alpha_{1 \mathrm{D}^{-}}$-adrenoceptors are all capable to form homodimers and homotrimers (Vicentic et al. 2002). Oligomerization of $\alpha_{1 \mathrm{~B}}$-adrenoceptors seems to be required for proper receptor function, since mutations of putative key hydrophobic residues in transmembrane domain TM1 and transmembrane domain TM4 prevent receptor oligomerization and result in impaired $\alpha_{1 \mathrm{~B}}$-adrenoceptor cell-surface expression and signaling (Lopez-Gimenez et al. 2007. $\alpha_{1}$-adrenoceptors are also capable to heterodimerize (Uberti et al. 2003, 2005, Hague et al. 2004a).

The subcellular localization of the $\alpha_{1}$-adrenoceptor subtypes can also confer distinct receptor function, as known to occur with other G-protein-coupled receptors (for review see Gobeil et al. 2006). The presence of intracellular $\alpha_{1}$-adrenoceptors has been described in the literature (Piascik and Perez 2001, Hirasawa et al. 2001, Toews et al. 2003). Studies with recombinant receptor have identified a characteristic distribution of $\alpha_{1 \mathrm{~A}}$-adrenoceptors throughout the cytoplasm of the cell, whereas $\alpha_{1 \mathrm{~B}}$-adrenoceptors mainly present classic plasma membrane labeling pattern (Hirasawa et al. 1997, Sugawara et al. 2002). Intracellular staining of $\alpha_{1 \mathrm{~A}}$-adrenoceptors in epithelial cells of the epididymis, vas deferens and seminal vesicle of rats has been also reported (Queiróz et al. 2008), confirming that this location of the receptor might be important in physiological events. In human prostatic smooth muscle cells, approximately $40 \%$ of the $\alpha_{1}$-adrenoceptors were intracellular, particularly concentrated around the nucleus (Mackenzie et al. 2000). Similar results were observed in cultured vascular smooth muscle cells and rat-1 fibroblasts transfected with the $\alpha_{1}$-adrenoceptor subtypes, although significant expression of $\alpha_{1 \mathrm{~A}}$-adrenoceptor in these cells was located in the plasma membrane (Hrometz et al. 1999, McCune et al. 2000). Conversely, $\alpha_{1 \mathrm{D}}$-adrenoceptors are expressed almost exclusively in the intracellular compartment from different cell types (Hirasawa et al. 1997, McCune et al. 2000, Chalothorn et al. 2002, Hague et al. 2004b), probably because of the Nterminal region of the protein that regulates expression of functional receptors in the cell membrane (Hague et al. 2004a, b). $\alpha_{1}$-adrenoceptors can bind competitively to the fluorescent antagonist BODIPY FL-prazosin (Daly et al. 1998, Mackenzie et al. 2000, Sugawara et al. 2002), raising the possibility that these receptors are probably functional and involved in signal transduction. Possible ligands for these intracellular receptors could be catecholamines penetrating the cells either by diffusion/lipophilicity or through transport by transmembrane carriers in postsynaptic cells (Mackenzie et al. 2000, Haag et al. 2004).

Functional, molecular and radioligand binding studies have been extensively used to characterize function and tissue distribution of $\alpha_{1}$-adrenoceptor in different tissues from different species, including humans (Langer 1999, Zhong and Minneman 1999, Varma and Deng 2000, Rokosh et al. 1994, Hieble et al. 1995, Price et al. 1994a, b, Rudner et al. 1999, Silva et al. 1999, Errasti et al. 2003, Scarparo et al. 2004). The heterogeneity of $\alpha_{1}$-adrenoceptors is a common finding in tissues of the male reproductive tract of rats and humans, including testis, prostate (Rokosh et al. 1994, Scofield et al. 1995, Nasu et al. 1996, 1998, Patrão et al. 2008), testis capsule (Jurkiewicz et al. 2006), seminal vesicle (Silva et al. 1999, Mendes et al. 2004, Patrão et al. 2008) and epididymis (Queiróz et al. 2002, Patrão et al. 2008). In all these tissues, a predominance of the Adrala mRNA subtype is observed. High abundance of Adrald transcripts is found in rat cauda epididymis (Queiróz et al. 2002), seminal vesicle (Silva et al. 1999, Mendes et al. 2004) and human prostate (Nasu et al. 1998, Moriyama et al. 1996), while vas deferens, epididymis and other genitourinary tissues present abundant Adrala and Adrald mRNAs with relative low levels of Adralb transcripts (Piascik et al. 1997, Queiróz et al. 2002). Levels of Adralb and Adrald mRNAs vary during rat brain development, showing that different receptor subtypes may have different ontogenic patterns of distribution leading to differential tissue response during development (McCune and Hill 1995, AlonsoLlamazares et al. 1998). 
Functional studies also reveal that a predominant population of $\alpha_{1 \mathrm{~A}}$-adrenoceptors is involved in the contractile response of smooth muscle from vas deferens, prostate and seminal vesicle (Mallard et al. 1992, Aboud et al. 1993, Yazawa and Honda 1993, Lepor et al. 1994, Teng et al. 1994, Burt et al. 1995, 1998, Pupo 1998, Silva et al. 1999). Interestingly, the presence of $\alpha_{1 \mathrm{~A}^{-}}$ and $\alpha_{1 \mathrm{~B}}$-adrenoceptors is detected in rat vas deferens by radioligand binding studies (Hanft and Gross 1989, Sallés and Badia 1991, Vivas et al. 1997), indicating that the correlation of binding and functional assays are not always directly correlated (Zhong and Minneman 1999). However, the contractions of vas deferens from cyproterone acetate-treated rats involves the participation of both $\alpha_{1 \mathrm{~A}^{-}}$and $\alpha_{1 \mathrm{~B}}$-adrenoceptors, indicating that this antiandrogen induces plasticity in the functional $\alpha_{1}$ adrenoceptor subtypes in the rat vas deferens (Campos et al. 2003). Divergence between receptor detection through functional methods versus molecular biology methods has also been discussed by Forray et al. (1994) and MacKinnon et al. (1994). Participation of $\alpha_{1 \mathrm{~A}^{-}}$ adrenoceptor in the contractile response of cauda epididymis from mouse (Hib and Caldeyro-Barcia 1974), in spontaneous contractions of rat epididymis regions ( $\mathrm{Da}$ Silva et al. 1975, Hib 1976, Chaturapanich et al. 2002) and in events related to epithelial function such as electrolyte transport (Leung et al. 1992, Chan et al. 1994) and protein processing (Ricker et al. 1996) have been reported. A predominant population of $\alpha_{1 \mathrm{~A}}$-adrenoceptor in rat epidiymis has been also confirmed by radioligand binding assays (Queiróz et al. 2002) and immunohistochemistry, which located this receptor subtype in smooth muscle and in subpopulations of epithelial cells from human and rat epididymis (Queiróz et al. 2008) and rhesus monkey (Patrão et al. 2008). The expression of different $\alpha_{1}$-adrenoceptor mRNA subtypes are known to occur along rat epididymis (Queiróz et al. 2002), raising the possibility of possible differential importance of $\alpha_{1}$-adrenoceptor subtypes in different epididymal cells during physiological and pathological events, including effects on male fertility. In fact, studies by Bhathal et al. (1974) and Ratnasooriya and Wadsworth (1990, 1994) have shown that the rat epididymis is significantly affected by $\alpha_{1}$-adrenoceptor blockade. In vivo treatment with different $\alpha_{1}$-adrenoceptor antagonists induces a decrease in ejaculatory capacity associated with a reduction in the fertilization ability of the sperm, suggesting a role for the sympathetic nervous system in fertility maintenance via $\alpha_{1}$-adrenoceptors (Ratnasooriya and Wadsworth 1990, 1994).

Although it is known that, in most tissues, mixtures of $\alpha_{1}$-adrenoceptor subtypes (mRNA and protein) are concomitantly expressed, with variable relative expression levels (Zhong and Minneman 1999), quantification and localization of all three $\alpha_{1}$-adrenoceptor subtypes at protein level have been difficult to be determined mainly due to the lack of pharmacological tools with selectivity or specificity, and the high degree of conservation of the $\alpha_{1}$-adrenoceptor subtypes. Selective antibodies against ADRA1A, ADRA1B and ADRA1D have been successfully reported in few studies. Detection of these proteins in tissue extracts by Western blot analysis has been shown with different rat tissues, including vas deferens and prostate (Manni et al. 2005, 2006, Shen et al. 2000). Immunohistochemical detection of ADRA1A in human prostate (Walden et al. 1999), human peripheral blood lymphocytes (Tayebati et al. 2000) and in different tissues of the male reproductive tract of rats, humans (Queiróz et al. 2008) and rhesus monkeys (Patrão et al. 2008) have also been reported.

Regulation of $\alpha_{1}$-adrenoceptors has been shown to occur under a variety of conditions, including hypoxia, ischemic reperfusion, catecholamine stimulation, cAMP levels, growth factors, hormonal factors and ageing (Markus and Avellar 1997, Zuscik et al. 1999, Gao and Kunos 1993, 1994, Ramarao et al. 1992, Rokosh et al. 1996, Michelotti et al. 2003, Queiróz et al. 2002, Mendes et al. 2004). In fact, changes in androgen status with either sexual maturation or castration differentially regulate the expression of $\alpha_{1}$-adrenoceptor subtypes in several tissues, including the male reproductive tract of different species (MacDonald and MacGrath 1980, Petitti et al. 1992, Shima 1992, Karkanias et al. 1996, Lacey et al. 1996, Pupo 1998, Homma et al. 2000, Queiróz et al. 2002, Quesada and Etgen 2002, Mendes et al. 2004, Campos et al. 2003, Queiróz et al. 2008). $17 \beta$-estradiol has been shown to increase $\alpha_{1 \mathrm{~B}}$-adrenoceptor binding sites and its pharmacological 
response to agonist stimulation in the hypothalamus and preoptic area of female rats (Petitti et al. 1992, Karkanias et al. 1996, Quesada and Etgen 2002), suggesting that regulation of $\alpha_{1}$-adrenoceptor by steroid hormones may be dependent on the gender analyzed.

$\alpha_{1}$-adrenoceptor antagonists are extensively used in the treatment of hypertension and lower urinary tract symptoms associated with benign prostatic hyperplasia (Roehrborn and Schwinn 2004). Clinical studies have reported ejaculatory dysfunction in patients submitted to treatment with $\alpha_{1}$-adrenoceptor antagonists, especially in those treated with tamsulosin and silodosin, which are selective to $\alpha_{1 \mathrm{~A}}$-adrenoceptors (Debruyne 2000, van Dijk et al. 2006). It has been reported that in vivo treatment of rats with different $\alpha_{1}$-adrenoceptor antagonists induces a decrease in the ejaculatory capacity associated with a reduction in the fertilization ability of the sperm (Ratnasooriya and Wadsworth 1990, 1994). Recently, Sanbe et al. (2007) have confirmed that the male mouse, with targeted disruption of all $\alpha_{1}$-adrenoceptor subtypes ( $\alpha_{1}$-adrenoceptor triple-knockout mouse), is infertile due to an impairment of sperm ejaculation caused by the loss of normal contractility mainly induced by $\alpha_{1 \mathrm{~A}}$-adrenoceptor in the vas deferens. However, the fertilization ability of the isolated sperm and sperm motility of these animals are normal.

\section{RELAXIN RECEPTORS: EXPRESSION AND FUNCTION IN THE MALE REPRODUCTIVE TRACT}

In addition to the influence of steroid hormones and neurotransmitters, the male reproductive tissues are also under control of other factors and hormones. Relaxin is one the novel peptide hormones which can be important for the normal male reproductive function.

Relaxin is a $6 \mathrm{kDa}$ peptide that belongs to a superfamily of hormones structurally related to insulin, which also includes, among others, the insulin-like growth factors (IGFs) and the insulin-like peptide from Leydig cells (INSL3) (for review see Sherwood 2004). Relaxin was initially detected only in females as a hormone to help parturition, but it has several other functions related or not with the reproductive function (for review see Sherwood 2004, Bathgate et al. 2006). Some of the relaxin actions, such as induction of collagen remodeling and softening of the cervix to help parturition, inhibition of uterine contractility and stimulation of mammary glands growth and differentiation, have been known for a long time. Recently, several other activities, related or not with the reproductive function have been attributed to relaxin, including the dilation of blood vessels in several tissues, a positive chronotropic action, the release of histamine from mastocytes, reduction of platelet aggregation, stimulation of thirst and vasopressin secretion, stimulation of prolactin release, and antifibrotic and antiapoptotic effects, to name a few.

In humans, three forms of relaxins (relaxins 1, 2 and 3 ) are found and they are encoded by three different genes ( $\mathrm{H} 1, \mathrm{H} 2$ and $\mathrm{H} 3)$. The $\mathrm{H} 1$ and $\mathrm{H} 2$ genes are localized in the short arm of the chromosome 9, and probably resulted from gene duplication during the evolution of the primates. The $\mathrm{H} 3$ gene is localized in the chromosome 19, near to the gene that encodes INSL3. The H2 gene is expressed in ovary, placenta, decidua and prostate gland (Gunnersen et al. 1996) and the H1 gene only in the last three tissues (Hansell et al. 1991). The recently discovered H3 gene (Bathgate et al. 2002) appears to be mainly expressed in the brain. Although the aminoacid sequences of the relaxins $\mathrm{H} 1$ and $\mathrm{H} 2$ differ considerably, their biological activity is similar, whereas the biological activity of the relaxin $\mathrm{H} 3$ is higher.

Only two forms of relaxin have been described in rodents. The relaxin 1 in these animals is encoded by an ortologue of the $\mathrm{H} 2$ gene in humans. The relaxin 3 in mouse and rat is derived from an orthologue of the $\mathrm{H} 3$ gene (Bathgate et al. 2002, Burazin et al. 2002). The only form of relaxin so far detected in plasma from pregnant animals is derived from the $\mathrm{H} 2$ gene and its orthologues in various species.

Relaxin was discovered in 1926 by Frederic L. Hisaw, who found that the injection of serum from pregnant guinea pigs or rabbits into virgin guinea pigs induced a relaxation of the pubic ligament (Hisaw 1926). The active principle was extracted in 1930 (Fevold et al. 1930), but the purified hormone was only obtained in 1974 (for review see Sherwood 2004). Relaxin is composed of two peptide chains, A and B, which are linked by disulphide bonds. The binding site to the receptors is localized in the B chain, while the A chain determines the binding specificity. Similar to insulin, relaxin is synthesized from a precursor, pre-prorelaxin, by sequen- 
tial proteolytic digestion of the signal peptide and the peptide that connects the two peptide chains (Ivell and Einspanier 2002).

Although relaxin was discovered a long time ago, the identity of its receptors remained unknown until 2002, when Hsu et al. described that relaxin could bind to and activate the G-protein-coupled receptors (GPCRs) RXFP1 and RXFP2, formerly known as LGR7 and LGR8, respectively. The human relaxins $\mathrm{H} 1$ and $\mathrm{H} 2$ and porcine relaxin 1 strongly bind to and activate both RXFP1 and RXFP2 with almost the same affinity, but the rat relaxin 1 binds only weakly to RXFP2 (Hsu et al. 2002, Scott et al. 2005). Although relaxin can bind to and activate both the recombinant RXFP1 and RXFP2 expressed in HEK 293 cells (Hsu et al. 2002), it is now recognized that RXFP1 is the endogenous receptor for relaxin, and RXFP2 the endogenous receptor for INSL3 (Zimmermann et al. 1999, Feng et al. 2006).

These two receptors belong to a subfamily of GPCRs, now called leucine-rich repeat-containing GPCRs (LGRs), which also includes the receptors for the gonadotropins LH and FSH, the TSH receptor and the more recently described sea anemone LGR (Nothacker and Grimmelikhuijzen 1993), snail LGR (Tensen et al. 1994), fruit fly LGR1 and LGR2 (Hauser et al. 1997, Nishi et al. 2000), nematode LGR (Kudo et al. 2000) and the LGRs 4, 5 and 6 (Hsu et al. 2000, 2002). Some of these LGRs (LGR 1 to 6) have still unknown ligands. Relaxin 3 binds to RXFP1, but probably its physiological target is the small peptide-like RXFP3 (Liu et al. 2003), the formerly orphan receptor GPCR 135 (for review see Bathgate et al. 2006, Halls et al. 2007).

All members of the LGR subfamily contain a large extracellular amino terminal domain consisting of three subdomains: a N-terminal cysteine-rich subdomain (NCR) followed by a leucine-rich repeat-containing subdomain (LRR subdomain) and a C-terminal cysteinesubdomain (CCR). The leucine-rich repeats in the LRR subdomain presents several $\beta$-strands and have been postulated to form a horseshoe shape which is important for hormone binding (Jiang et al. 1995). The CCR subdomain is a hinge region that allows contact between the amino terminal region and the transmembrane domains of the receptor after activation by the hormone. Another interesting feature is that RXFP1 and RXFP2 are distin- guished from other members of the LGR subfamily, and from other GPCRs in general, by a unique low-density lipoprotein class A module (LDL-A) at the aminoterminus of the ectodomain. Studies with chimeras between RXFP1 and RXFP2 revealed that both the ectodomain and the transmembrane domain of the receptors are necessary for optimal binding and signal transduction (Halls et al. 2005). The unique LDL-A module of RXFP1 and RXFP2 seems crucial for activation of receptor signaling (Scott et al. 2006, Kern et al. 2007).

Relaxin can increase cyclic AMP after interacting with recombinant RXFP1 and RXFP2 in heterologous systems (Hsu et al. 2002, Sudo et al. 2003, Halls et al. 2006). Relaxin can also stimulate endogenous receptors to increase cyclic AMP in many reproductive (Sanborn et al. 1980, Cheah and Sherwood 1980, Judson et al. 1980, Braddon 1978) and non-reproductive tissues (Bathgate et al. 2006), and other downstream signaling reactions can be activated after the production of cyclic AMP, such as tyrosine kinase or mitogen-activated protein kinase activation, and inhibition of phosphodiesterase (for review see Bathgate et al. 2006, Halls et al. 2007). The accumulation of cyclic AMP induced by relaxin in cells that endogenously express RXFP1 involves a time-dependent biphasic pathway: an early phase that involves coupling to Gs, and a delayed phase that involves activation of $\mathrm{PI} 3 \mathrm{~K}$ and $\mathrm{PKC} \zeta$. In cells expressing the recombinant RXFP1, studies confirmed this biphasic pattern of cyclic AMP stimulation by relaxin, and showed that the delayed phase involving PI3K and PKC was dependent on $\beta \gamma$ subunits of the $\mathrm{G} \alpha_{\mathrm{i} 3}$. Activation of recombinant RXFP2 by INSL3, on the other hand, involved an initial activation of $\mathrm{G} \alpha_{\mathrm{s}}$ that was modulated by an inhibition mediated by $\mathrm{G} \alpha_{\mathrm{oB}}$ and the release of inhibitory G- $\beta \gamma$ subunits (Halls et al. 2006). Therefore, initially both RXFP1 and RXFP2 stimulate cyclic AMP accumulation, but RXFP1 also activates a delayed pathway that further increases cyclic AMP accumulation.

With the recent availability of knockout animals for relaxin or its receptors, it has been possible to establish the physiological importance of this hormone. Relaxin has an antifibrotic effect in several tissues, and the relaxin knockout mouse is a model of fibrosis (Samuel et al. 2003a, b, 2005). Relaxin interferes with collagen metabolism and increases the expression and activity of 
metalloproteinases (MMPs) in uterine, cardiac, vascular and renal tissues (Jeyabalan et al. 2003, 2007, Lenhart et al. 2001, Mookerjee et al. 2005).

In the reproductive tract of female mice, the disruption of relaxin or Rxfpl gene causes the same abnormalities: an absence of the relaxation and the elongation of the interpubic ligament and impaired nipple development (Zhao et al. 1999, Krajnc-Franken et al. 2004).

The physiological role of relaxin in the male is not so well defined and we will next present some data obtained in our laboratory and from the literature related to the role of relaxin in the male reproductive tissues.

The main evidence of the important role of relaxin for male reproductive function came from observations in transgenic mice with a disruption of relaxin or relaxin receptor genes. In male mice, the disruption of the relaxin gene causes a delayed development of the reproductive tract, with an arrest of sperm maturation (Samuel et al. 2003a), but the disruption of Rxfpl does not alter testes or prostate (Kamat et al. 2004), and impairs spermatogenesis and reduces fertility only in the first generations of knockout animals (Krajnc-Franken et al. 2004). The interaction of INSL3 with RXFP2 controls the differentiation of the gubernaculum, the caudal genitoinguinal ligament critical for testicular descent, and deletion of Ins13 or Rxfp2 causes cryptorchidism (Zimmermann et al. 1999). Transgenic overexpression of relaxin did not prevent cryptorchidism in Insl3knockout animals (Feng et al. 2006). These observations strongly support the idea that, although both RXFP1 and RXFP2 can bind relaxin in vitro, relaxin does not physiologically activate RXFP2. Nevertheless, a contribution of RXFP2 to the actions of relaxin in some species cannot be completely excluded.

The relaxin source in males seems to vary depending on the species. In humans and many other mammals, relaxin is produced by the prostate and released almost exclusively in the seminal fluid. The relaxin mRNA has been detected in human prostate by RT-PCR and in situ hybridization (for review see Sherwood 2004, Ivell et al. 1989, Gunnersen et al. 1996, Bogic et al. 1995). There are few reports on immunohistochemical localization of relaxin in the male tract. Relaxin immunostaining has been detected in the human prostate, seminal vesicle and ampullary part of the vas deferens (Sokol et al. 1989, Yki-Jarvinen et al. 1983). In other species, testis (shark) or seminal vesicle (boar) may be the main source of the hormone (Steinetz et al. 1998, Kohsaka et al. 1992). The source of relaxin in the male rat is controversial. Immunohistochemistry studies have failed to demonstrate relaxin expression in testis, prostate, seminal vesicle and epididymis (Anderson et al. 1986), but the mRNA for relaxin has been detected in prostate and testis (Gunnersen et al. 1995).

Regarding the expression of relaxin receptors in the various tissues of the male tract, data available in the literature are scarce. Transcripts for both RXFP1 and RXFP2 have been identified in the whole rat testis and in germ cells (Anand-Ivell et al. 2006, Filonzi et al. 2007), but in primary culture of Sertoli cells only RXFP1 has been found (Filonzi et al. 2007). Rxfp2 but not Rxfp1 transcripts are present in Leydig cells. The RXFP1 protein has been detected in elongated spermatids and in rat Sertoli cells (Filonzi et al. 2007), and the RXFP2 protein in human Leydig and germ cells (Anand-Ivell et al. 2006). The role of relaxin receptors in the adult testis remains to be determined. Since RXFP1 receptors are expressed in germ cells during specific stages of the development, one may speculate that relaxin participates in the spermatogenic process. In addition, the localization of RXFP1 receptors in Sertoli cells suggests that the hormone plays a role in spermatogenesis. Data about the role of relaxin in mature spermatozoa are controversial. Whereas some data in the literature support a role for relaxin in sperm motility (Sarosi et al. 1983, Essig et al. 1982), we detected only low levels of Rxfpl mRNA in mature spermatozoa, and RXFP1 protein was undetectable (Filonzi et al. 2007). Other studies have also failed to find an effect of relaxin on sperm function (Jockenhovel et al. 1990, Newinger et al. 1990).

The transcripts of $R x f p 1$ and $R x f p 2$ are present in the caput and cauda regions of the rat epididymis (Filonzi et al. 2007). $R x f p 2$ transcripts were also found in the human epididymis (Anand-Ivell et al. 2006). Transcripts of Rxfp 1 and Rxfp 2 have also been identified in the seminal vesicle, but in the prostate only Rxfpl mRNA was detected (Filonzi et al. 2007).

The levels of RXFP1 and RXFP2 receptor transcripts were particularly high in the vas deferens and comparable to the levels seen in the testis (Filonzi et al. 
2007). Strong immunostaining for RXFP1 and RXFP2 was seen in the apical portion of epithelial cells, in the longitudinal and circular muscular layers, and in the arteriolar wall of blood vessels of the vas deferens. Although relaxin is classically known to reduce uterine tone (Sanborn et al. 1980, for review see Sherwood 2004), it does not affect the contractility of the vas deferens. In this tissue, however, relaxin may be involved in other functions. RXFP1 receptors detected in the arteriolar walls may control local vascular resistance (Filonzi et al. 2007). Furthermore, relaxin increases the expression of metaloproteinase 7 gene in the vas deferens, which may be involved in collagen and matrix remodeling and/ or apoptosis (Ii et al. 2006). In fact, a significant increase in the collagen expression in the prostate and testis of relaxin knockout mice has been documented before (Samuel et al. 2003a). It remains to be investigated whether RXFP1 receptors in the epithelium of the vas deferens are involved in the regulation of secretion.

\section{CONCLUSIONS}

Muscarinic acetylcholine receptors, $\alpha_{1}$-adrenoceptors and relaxin receptors are often co-localized in tissues of the male reproductive system and may act in concert to regulate several aspects of reproduction. In testis, all subtypes of muscarinic acetylcholine receptors are found in Sertoli cells, where they might counteract FSH-induced cyclic AMP accumulation, influence protein synthesis, cell proliferation and cell junction dynamics. The relaxin receptor RXFP1 expressed in Sertoli cells increases cell proliferation and may also affect protein synthesis, acting in the same direction as FSH. These receptors may therefore indirectly affect spermatogenesis. In addition, RXFP1 is found in late stage germ cells, and muscarinic acetylcholine receptors are found in spermatozoa, supporting their role in spermatogenesis. All these GPCRs are widely distributed in the excurrent ducts of the male tract: efferent ducts, epididymis and vas deferens. Their localization in epithelial cells suggests a role in secretory and absorptive processes, and they may stimulate protein synthesis, therefore affecting sperm composition. Muscarinic acetylcholine receptors and $\alpha_{1}$-adrenoceptor are also involved in the modulation of the contraction of smooth muscle cells lining these ducts, while the re- laxin receptor is more likely involved in the architecture of these tissues. Muscarinic acetylcholine receptors and $\alpha_{1}$-adrenoceptors are also involved in events of protein secretion, mitosis, differentiation and smooth muscle contraction in seminal vesicle and prostate.

Although several aspects of muscarinic acetylcholine receptors, with $\alpha_{1}$-adrenoceptors and relaxin receptors have been clarified in the recent years, much still remains to be elucidated about their relative contribution and interaction to control male reproductive function, as well as the mechanisms involved in the regulation of their expression and respective intracellular signaling induced upon activation by a ligand. These studies will certainly provide information that may aid the therapeutics of male infertility and male contraception, since receptors are targets for the development of selective therapeutic agents and pharmacological manipulation of physiological processes.

\section{ACKNOWLEDGMENTS}

The studies conducted in the Section of Experimental Endocrinology and cited in the present review were supported in part by grants from Fundação de Amparo à Pesquisa do Estado de São Paulo (FAPESP), Conselho Nacional de Desenvolvimento Cientifico e Tecnológico $(\mathrm{CNPq})$ and the National Institute of Child Health and Human Development/National Institute of Health through cooperative agreement U54-HD35 041 as part of the specialized cooperative Centers Program in Reproduction and by the T.W. Fogarty International Center for Training and Research in Population and Health, USA D43TW/HD00 627 (subcontract UNIFESP/UNC 5-53 284). The authors declare that there is no conflict of interest that could prejudice the impartiality of this work. M.C.W.A. and C.S.P. are research fellows from CNPq. The authors thank Espedita M.J. Silva Santos and Luciana Honda for technical assistance.

\section{RESUMO}

Esta revisão enfatiza a expressão e a função dos receptores muscarínicos, adrenoceptores $\alpha_{1}$ e receptores para relaxina no sistema reprodutor masculino. A expressão dos receptores muscarínicos e adrenoceptores $\alpha_{1}$ em compartimentos específicos de dúctulos eferentes, epidídimo, ductos deferentes, vesí- 
cula seminal e próstata de várias espécies indica o envolvimento destes receptores na modulação da composição do fluido luminal e na contração do músculo liso, incluindo efeitos na fertilidade masculina. Além disso, a ativação dos receptores muscarínicos leva à transativação do receptor para o fator crescimento epidermal e proliferação das células de Sertoli. Os receptores para relaxina estão presentes no testículo, RXFP1 nas espermátides alongadas e células de Sertoli de rato e RXFP2 nas células de Leydig e germinativas de ratos e humano, sugerindo o envolvimento destes receptores no processo espermatogênico. A localização de ambos os receptores na porção apical das células epiteliais e no músculo liso dos ductos deferentes de rato sugere um papel na contração e na regulação da secreção.

Palavras-chave: receptores muscarínicos, adrenoceptores $\alpha_{1}$, receptores para relaxina, sistema reprodutor masculino.

\section{REFERENCES}

Aboud R, Shafil M AND Docherty JR. 1993. Investigation of the subtypes of $\alpha_{1}$-adrenoceptor mediating contractions in the rat aorta, vas deferens and spleen. $\mathrm{Br} \mathrm{J}$ Pharmacol 109: 80-87.

Alonso-Llamazares A, López-Alonso J, Del Barrio M, Casanova E, Calvo P and Chinchetru M. 1998. Cloning of chicken and mouse alpha $1 \mathrm{~b}$ adrenergic receptor. Biochim Biophys Acta 1396: 263-266.

ANAND-IVEll RJ, RELAN V, BALVERS M, COIFFECDORVAL I, FRITSCH M, BATHGATE RA AND IVELL R. 2006. Expression of the insulin-like peptide 3 (INSL3) hormone-receptor (LGR8) system in the testis. Biol Reprod 74: 945-953.

Anderson MB, Collado-Torres M ANd VAupel MR. 1986. Absence of relaxin immunostaining in the male reproductive tracts of the rat and mouse. J Histochem Cytochem 7: 945-948.

Ban Y, Sato T, Nakatsuka T, Kemi M, Samura K, Matsumoto H, Cukierski MA AND VAN ZWieten MJ. 2002. Impairment of male fertility induced by muscarinic receptor antagonists in rats. Reprod Toxicol 16: 757-765.

BAthgAte RA ET AL. 2002. Human relaxina gene 3 (H3) and the equivalent mouse relaxin (M3) gene. J Biol Chem 277: 1148-1157.

Bathgate RA, IVell R, SANborn BM, Sherwood OD AND SUMMERS RJ. 2006. International union of pharmacology LVII: recommendations for the nomenclature of receptors for relaxin family peptides. Pharmacol Rev 58: 7-31.

BERNARD V, LEVEY AI AND BLOCH B. 1999. Regulation of the subcellular distribution of $\mathrm{m} 4$ muscarinic acetylcholine receptors in striatal neurons in vivo by the cholinergic environment: evidence for regulation of cell surface receptors by endogenous and exogenous stimulation. J Neurosci 19: 10237-10249.

Bernard V, Brana C, Liste I, Lockridge O And BLOCH B. 2003. Dramatic depletion of cell surface $\mathrm{m} 2$ muscarinic receptor due to limited delivery from intracytoplasmic stores in neurons of acetylcholinesterase-deficient mice. Mol Cell Neurosci 23: 121-133.

Bhathal PS, Gerkens JF AND MAShFord ML. 1974. Spermatic granuloma of the epididymis in rats treated with guanethidine. J Pathol 112: 19-26.

Birdsall NJ AND LAZARENo S. 2005. Allosterism at muscarinic receptors: ligands and mechanisms. Mini Rev Med Chem 5: 523-543.

BISHOP MJ. 2007. Recent advances in the discovery of alpha1-adrenoceptor agonists. Curr Top Med Chem 7: 135-145.

Blanco M And Robinson MJ. 2004. Muscarinic M3 acetylcholine receptor immunostaining in paraffin-embedded normal and neoplastic prostatic gland tissue. Ann Diagn Pathol 8: 333-336.

Bogic L, Madel M And BRyant-Greenwood GD. 1995. Relaxin gene expression in human reproductive tissues by in situ hybridization. J Clin Endocrinol Metabol 80: 130-137.

Borges MOR, Abreu MLC, Porto CS And Avellar MC. 2001. Characterization of muscarinic acethylcholine receptor in rat Sertoli cells. Endocrinology 142: 47014710.

BRADDON SA. 1978. Relaxin-dependent adenosine 3',5'monophosphate concentration changes in the mouse pubic symphysis. Endocrinology 102: 1292-1299.

Brodde OE AND LeINEWEBER K. 2004. Autonomic receptor systems in the failing and aging human heart: similarities and differences. Eur J Pharmacol 500: 167-176.

BurAZIN TC, BATHGATE RAD, MACRIS M, LAYFIELS S, Gundlach AL AND TREgeAR GW. 2002. Restricted but abundant expression of the novel rat gene-3 (R3) relaxin in the dorsal tegmental region of brain. J Neurochem 82: $1553-1557$.

Burt RP, Chapple CR And Marshall I. 1995. Evidence for a functional alpha 1A- (alpha 1C-) adrenoceptor mediating contraction of the rat epididymal vas deferens and 
an alpha 1B-adrenoceptor mediating contraction of the rat spleen. Br J Pharmacol 115: 467-475.

Burt RP, Chapple CR and Marshall I. 1998. Alpha1A-adrenoceptor mediated contraction of rat prostatic vas deferens and the involvement of ryanodine stores and $\mathrm{Ca}^{2+}$ influx stimulated by diacylglycerol and PKC. Br J Pharmacol 123: 317-325.

Campos M, Morais PL And Pupo AS. 2003. Effects of castration and of testosterone replacement on alpha1-adrenoceptor subtypes in the rat vas deferens. Eur J Pharmacol 471: 149-156.

CAUlfield MP AND BIRdsall NJM. 1998. International Union of Pharmacology. XVII. Classification of muscarinic acetylcholine receptors. Pharmacol Rev 50: 279290.

Chalothorn D, McCune DF, Edelmann SE, GarciaCazarin ML, Tsujimoto G and Piascik MT. 2002. Differences in the cellular localization and agonist-mediated internalization properties of the alpha(1)-adrenoceptor subtypes. Mol Pharmacol 61: 1008-1016.

Chan HC, Fu WO, Chung YW, Zhou TS AND Wong PYD. 1994. Adrenergic receptors on cultured rat epididymal cells: regulation of $\mathrm{Cl}^{-}$conductances. Biol Reprod 51: 1040-1045.

Chang DJ, Chang TK, Yamanishi SS, Salazar FH, Kosaka AH, Khare R, Bhakta S, Jasper JR, SHIEH IS AND LERNICK JD. 1998. Molecular cloning, genomic characterization and expression of novel human

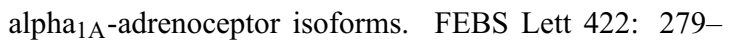
283.

Chaturapanich G, Maythaarttaphong S, VerawatNAPAKUL V AND PhOLPRAMOOL C. 2002. Mediation of contraction in rat cauda epididymidis by alpha-adrenoceptors. Reproduction 124: 887-892.

Cheah SH And Sherwood OD. 1980. Target tissues for relaxin in the rat: tissue distribution of injected 125I-labeled relaxin and tissue changes in adenosine 3',5'-monophosphate levels after in vitro relaxin incubation. Endocrinology 106: 1203-1209.

Chen S, Lin F, IismaA S, Lee KN, Birckbichler PJ AND GRAHAM RM. 1996. Alpha1-adrenergic receptor signalling via $\mathrm{Gh}$ is subtype specific and independent of its transglutaminase activity. J Biol Chem 271: 3238532391.

Chen S, Xu M, Lin F, Lee D, Riek P and Graham RM. 1999. Phe310 in transmembrane VI of the alpha1Badrenergic receptor is a key switch residue involved in activation and catecholamine ring aromatic bonding. J Biol Chem 274: 16320-16330.
COGÉ F ET AL. 1999. Truncated isoforms inhibit $\left[{ }^{3} \mathrm{H}\right]$ prazosin binding and cellular trafficking of native human $\alpha_{1 \mathrm{~A}^{-}}$ adrenoceptors. Biochem J 343: 231-239.

Da Silva MC, Gimeno MF and Gimeno AL. 1975. Physiologic and pharmacologic studies on the motility of isolated guinea-pig cauda epididymidis. Fertil Steril 26: 1250-1256.

Daly CJ, Milligan CM, Milligan G, Mackenzie JF AND MCGRATH JC. 1998. Cellular localization and pharmacological characterization of functioning alpha-1 adrenoceptors by fluorescent ligand binding and image analysis reveals identical binding properties of clustered and diffuse populations of receptors. J Pharmacol Exp Ther 286: 984-990.

DANIELS DV ET AL. 1999. Human cloned $\alpha_{1 \mathrm{~A}}$-adrenoceptor isoforms display $\alpha_{1 \mathrm{~L}}$-adrenoceptor pharmacology in functional studies. Eur J Pharmacol 370: 337-343.

Davenport CW And Heindel JJ. 1987. Cholinergic inhibition of cAMP accumulation in Sertoli cells cultured from immature hamsters. J Androl 8: 307-313.

DEBRUYNE FM. 2000. Alpha blockers: are all created equal? Urology 56: 20-22.

Deng XF, Chemtob S And VARMa DR. 1996. Characterization of $\alpha_{1 \mathrm{D}}$-adrenoceptor subtype in rat myocardium, aorta and other tissues. Br J Pharmacol 119: 269-276.

Diviani D, Lattion AL, Abuin L, Staub O And Cotecchia S. 2003. The adaptor complex 2 directly interacts with the alpha $1 \mathrm{~b}$-adrenergic receptor and plays a role in receptor endocytosis. J Biol Chem 278: 1933119340.

DOCHERTY JR. 1998. Subtypes of functional alpha1- and alpha2-adrenoceptors. Eur J Pharmacol 361: 1-15.

DOCHERTY JR. 2002. Age-related changes in adrenergic neuroeffector transmission. Auton Neurosci 96: 8-12.

Doggrell SA. 1986. M1 and M2-muscarinic receptors in the epididymal half of the rat vas deferens. Gen Pharmacol 17: 239-241.

Du JY, Zuo WL, Chen MH, Xiang H and Zhou WL. 2006. Involvement of muscarinic acetylcholine receptors in chloride secretion by cultured rat epididymal epithelium. Cell Biol Int 30: 741-746.

EGLEN RM. 2006. Muscarinic receptor subtype in neuronal and non-neuronal cholinergic function. 2006. Auton Autacoid Pharmacol 6: 219-233.

Eglen RM, Adham N And Whiting RL. 1992. Acute desensitization of muscarinic receptors in the isolated guinea-pig ileal longitudinal muscle. J Auton Pharmacol 12: $137-148$. 
EHRÉN I, SJÖSTRAND NO, HAMMARSTRÖM M AND WIKLUND NP. 1997. Is glandular formation of nitric oxide a prerequisite for muscarinic secretion of fructose in the guinea-pig seminal vesicle? Urol Res 25: 433-438.

EISENhofER G. 2001. The role of neuronal and extraneuronal plasma membrane transporters in the inactivation of peripheral catecholamines. Pharmacol Ther 91: 35-62.

Errasti AE, AVEllar MCW, Daray FM, TramonTANO J, LuCIANi LI, LinA BARd MJ, MarosticA E AND Rothlin RP. 2003. Human umbilical vein vasoconstriction induced by epinephrine acting on alpha1Badrenoceptor subtype. Am J Obstet Gynecol 189: 14721480.

Esbenshade TA, Hirasawa A, Tsujimoto G, TAnaka T, YANo J, Minneman KP AND Murphy TJ. 1995. Cloning of the human alpha 1d-adrenergic receptor and inducible expression of three human subtypes in SK-NMC cells. Mol Pharmacol 47: 977-985.

Essig M, Schoenfeld C, Amelar RD, Dubin L And WEISS G. 1982. Stimulation of human sperm motility by relaxin. Fertil Steril 38: 339-343.

Feng S, Bogatcheva NV, Kamat AA, Truong A And AgOULNIK AI. 2006. Endocrine effects of relaxin overexpression in mice. Endocrinology 147: 407-414.

FEVold HL, HisAw FL AND MEYER RK. 1930. The relaxative hormone of the corpus luteum. Its purification and concentration. J Am Chem Soc 52: 3340-3348.

Filonzi M, CARdoso LC, Pimenta MT, Queiróz DB, Avellar MC, Porto CS AND LAZARi MF. 2007. Relaxin family peptide receptors Rxfp1 and Rxfp2: mapping of the mRNA and protein distribution in the reproductive tract of the male rat. Reprod Biol Endocrinol 5: 29.

Ford APdW, Arredondo NF, Blue DR, Bonhaus DW, Jasper JR, KaVA MS, Lesnick J, Pfister JR, SHIEH IA AND Vimont RL. 1996. RS 17053, a selective $\alpha_{1 \mathrm{~A}}$ adrenoceptor antagonist, displays low affinity for functional $\alpha_{1 \mathrm{~A}}$ adrenoceptors in human prostate: implications for adrenoceptor classification. Mol Pharmacol 49: 209-215.

Ford APDW, DANiels DV, Chang DJ, GeVER JR, JASPER JR, LERNICK JD AND CLARKE DE. 1997. Pharmacological pleiotropism of the human recombinant alpha1A-adrenoceptor: implications for alpha1-adrenoceptor classification. Br J Pharmacol 121: 1127-1135.

Forray C, Bard JA, Wetzel JM, Chiu G, Shapiro E, TANG R, Lepor H, Hartig PR, Weinshank RL AND BRANCHEK TA. 1994. The alpha 1-adrenergic re- ceptor that mediates smooth muscle contraction in human prostate has the pharmacological properties of the cloned human alpha 1c subtype. Mol Pharmacol 45: 703-708.

FUKasaWa R, TANiguchi N, MORIYAMa N, UKaI Y, YAMAZAKI S, UEKI T, KAMEYAMA S, KimURA K AND KAWABE K. 1998. The alpha1L-adrenoceptor subtype in the lower urinary tract: a comparison of human urethra and prostate. Br J Urol 82: 733-737.

GAO B AND KunOs G. 1993. Isolation and characterization of the gene encoding the rat alpha $1 \mathrm{~B}$ adrenergic receptor. Gene 131: 243-247.

Gao B And Kunos G. 1994. Transcription of the rat alpha $1 \mathrm{~B}$ adrenergic receptor gene in liver is controlled by three promoters. J Biol Chem 269: 15762-15767.

Gobeil F Jr, Fortier A, Zhu T, Bossolasco M, Leduc M, Grandbois M, Heveker N, BKaily G, Chemtob S AND BARBAz D. 2006. G-protein-coupled receptors signalling at the cell nucleus: an emerging paradigm. Can J Physiol Pharmacol 84: 287-297.

GonzÁlez-EsPinosa C, RoMero-Ávila T, Mora-RoDRÍGUES TM, GONZÁLEZ-ESPINOSA D AND GARCÍASÁINS JA. 2001. Molecular cloning and functional expression of the guinea pig $\alpha_{1 \mathrm{a}}$ adrenoceptor. Eur J Pharmacol 426: 147-155.

Graham RM, Perez DM, Hwa J And Piascik MT. 1996. $\alpha_{1}$-adrenergic receptor subtypes: molecular structure, function and signalling. Circ Res 78: 737-749.

Grimm U, Fuder H, Moser U, Bumert HG, MutschLER E AND LAMBRECHT G. 1994. Characterization of the prejunctional muscarinic receptors mediating inhibition of evoked release of endogenous noradrenaline in rabbit isolated vas deferens. Naunyn Schmiedebergs Arch Pharmacol 349: 1-10.

GunNersen JM, CraWfor RJ AND Tregear GW. 1995. Expression of the relaxin gene in rat tissues. Mol Cell Endocrinol 10: 55-64.

Gunnersen JM, Fu P, Roche PJ And Tregear GW. 1996. Expression of human relaxin genes: characterization of a novel alternatively-spliced human relaxin mRNA species. Mol Cell Endocrinol 118: 85-94.

HaAg C, Berkels R, Gründemann D, Lazar A, TAubert D And SCHOMig E. 2004. The localisation of the extraneuronal monoamine transporter (EMT) in rat brain. J Neurochem 88: 291-297.

Hague C, Uberti MA, Chen Z, Hall RA And MinNEMAN KP. 2004a. Cell surface expression of alpha1Dadrenergic receptors is controlled by heterodimerization 
with alpha1B-adrenergic receptors. J Biol Chem 279: $15541-15549$.

Hague C, Chen Z, Pupo AS, Schulte N, Toews ML And Minneman K. 2004b. The N-terminus of the human \{alpha\}1D-adrenergic receptor prevents cell surface expression. J Pharmacol Exp Ther 309: 388-397.

Halls ML, Bond CP, Sudo S, Kumagai J, Ferraro T, LAYField S, BAthgate RA AND Summers RJ. 2005. Multiple binding sites revealed by interaction of relaxin family peptides with native and chimeric relaxin family peptide receptors 1 and 2 (LGR7 and LGR8). J Pharmacol Exp Ther 313: 677-687.

Halls ML, Bathgate RAD and Summers RJ. 2006. Relaxin family peptide receptors, RXFP1 and RXFP2, modulate cyclic AMP signalling by distinct mechanisms. Mol Pharmacol 70: 214-226.

Halls ML, van Der Westhuizen ET, Bathgate RAD AND SUMmers RJ. 2007. Relaxin family peptide receptors - former orphans reunite with their parent ligands to activate multiple signalling pathways. Br J Pharmacol 150: 677-691.

Hamamura M, Maróstica E, Avellar MCW And PORTO CS. 2006. Muscarinic acetylcholine receptor subtypes in the rat seminal vesicle. Mol Cell Endocrinol 247: 192-198.

HANFT G AND GROSS G. 1989. Subclassification of alpha 1adrenoceptor recognition sites by urapidil derivatives and other selective antagonists. Br J Pharmacol 97: 691-700.

Hansell DJ, Bryant-Greenwood GD AND GreenWOOD FC. 1991. Related Expression of the human relaxin $\mathrm{H} 1$ gene in the decidua, trophoblast, and prostate. J Clin Endocrinol Metab 72: 899-904.

HAUSER F, NothaCKER HP AND GRIMMELIKHUIJZEN CJ. 1997. Molecular cloning, genomic organization and developmental regulation of a novel receptor from Drosophila melanogaster structurally related to members of the thyroid-stimulating hormone, follicle-stimulating hormone, luteinizing hormone/choriogonadotropin receptor family from mammals. J Biol Chem 272: 1002-1010.

Hawrylyshyn KA, Michelotti GA, Cogé F, Guenin SP AND SCHWINN DA. 2004. Update on human alpha1adrenoceptor subtype signalling and genomic organization. Trends Pharmacol Sci 25: 449-455.

Hein P AND Michel MC. 2007. Signal transduction and regulation: are all alpha1-adrenergic receptor subtypes created equal? Biochem Pharmacol 73: 1097-1106.

Нів J. 1976. Effects of autonomic drugs on epididymal contractions. Fertil Steril 27: 951-956.
Hib J AND CAldeyro-BARCia R. 1974. Neurohormonal control of epididymal contractions. In: COUTINHO EM And Fuchs F (Eds), Physiology and Genetic of Reproduction, Part B, New York, Plenum Press, p. 111.

Hieble JP AND RUfFolo RR JR. 1996. The use of alphaadrenoceptor antagonists in the pharmacological management of benign prostatic hypertrophy: an overview. Pharmacol Res 33: 145-160.

Hieble JP, Bylund DB, Clarke De, Eikenburg DC, LANGER SZ, LEFKOWITZ RJ, Minneman KP AND RUFFOLO RR JR. 1995. International Union of Pharmacology. X. Recommendation for nomenclature of alpha 1-adrenoceptors: consensus update. Pharmacol Rev 47: $267-270$.

Hirasawa A, Shibata K, Horie K, TAKey Y, Obika K, TANaKa T, Muramoto N, TAKagaki K, Yano J AND Tsujimoto G. 1995. Cloning, functional expression and tissue distribution of human alpha 1C-adrenoceptor splice variants. FEBS Lett 363: 256-260.

Hirasawa A, Sugawara T, Awaji T, Tsumaya K, Ito H And Tsujimoto G. 1997. Subtype-specific differences in subcellular localization of alpha1-adrenoceptors: chlorethylclonidine preferentially alkylates the accessible cell surface alpha1-adrenoceptors irrespective of the subtype. Mol Pharmacol 52: 764-770.

Hirasawa A, Awaji T, Xu Z, Shinoura H and Tsujiмото G. 2001. Regulation of subcellular localization of alpha1-adrenoceptor subtypes. Life Sci 68: 2259-2267.

HISAW FL. 1926. Experimental relaxation of the pubic ligament of the guinea pig. Proc Soc Exp Biol Med 23: $661-663$.

Homma Y, Hamada K, Nakayama Y, Tsujimoto G AND KAWABE K. 2000. Effects of castration on contraction and alpha(1)-adrenoceptor expression in rat prostate. Br J Pharmacol 131: 1454-1460.

Horie K, ObiKa K, Foglar R And Tsujimoto G. 1995. Selectivity of the imidazoline alpha-adrenoceptor agonists (oxymetazoline and cirazoline) for human cloned alpha 1adrenoceptor subtypes. Br J Pharmacol 116: 1611-1618.

Hrometz SL, Edelmann SE, McCune DF, Olges JR, HADlEy RW, PEREZ DM AND PiAsCiK MT. 1999. Expression of multiple $\alpha_{1}$-adrenoceptors on vascular smooth muscle: correlation with the regulation of contraction. J Pharmacol Exp Ther 290: 452-463.

Hsu SY, Kudo M, Chen T, Nakabayashi K, Bhalla A, VAN DER SPEK PJ, VAN DUIN M AND HSUEH AJ. 2000. The three subfamilies of leucine-rich repeat-containing $\mathrm{G}$ protein-coupled receptors (LGR): identification of LGR6 
and LGR7 and the signalling mechanism for LGR7. Mol Endocrinol 14: 1257-1271.

Hsu SY, Nakabayashi K, Nishi S, Kumagai J, Kudo M, Sherwood OD ANd Hsueh AJ. 2002. Activation of orphan receptors by the hormone relaxin. Science 295: 671-674.

Hu K AND NatTel S. 1995. Mechanisms of ischemic preconditioning in rat hearts. Involvement of alpha 1B-adrenoceptors, pertussis toxin-sensitive $\mathrm{G}$ proteins, and protein kinase C. Circulation 92: 2259-2265.

HuleiHel M AND LunENFEld E. 2004. Regulation of spermatogenesis by paracrine/autocrine testicular factors. Asian J Androl 6: 259-268.

Hulme EC, Birdsall NJM and Buckley NJ. 1990. Muscarinic receptor subtypes. Ann Rev Pharmacol Toxicol 30: 633-673.

HwA J AND PEREZ DM. 1996. The unique nature of the serine interactions for alpha 1-adrenergic receptor agonist binding and activation. J Biol Chem 271: 6322-6327.

HWA J, Graham RM AND Perez DM. 1995. Identification of critical determinants of alpha 1-adrenergic receptor subtype selective agonist binding. J Biol Chem 270: 23189-23195.

Hwa J, Graham RM and Perez DM. 1996. Chimeras of alpha1-adrenergic receptor subtypes identify critical residues that modulate active state isomerization. J Biol Chem 271: 7956-7964.

II M, YAMAMOTO H, ADACHI Y, MARUYAMA Y AND SHINOMURA Y. 2006. Role of metalloproteinase-7 (matrilysin) in human cancer invasion, apoptosis, growth, and angiogenesis. Exp Biol Med 231: 20-27.

Iram S AND Hoyle CH. 2005. Potentiation of sympathetic neuromuscular transmission mediated by muscarinic receptors in guinea pig isolated vas deferens. Naunyn Schmiedebergs Arch Pharmacol 371: 212-220.

IVELL R AND EINSPANIER A. 2002. Relaxin peptides are new global players. Trends Endocrinol Metab 13: 343348 .

IVEll R, Hunt N, KHAN-DAwOod F AND DAWOOd MY. 1989. Expression of the human relaxin gene in the corpus luteum of the menstrual cycle and in the prostate. Mol Cell Endocrinol 66: 251-255.

JACKSON VM AND CUNNANE TC. 2001. Neurotransmitter release mechanisms in sympathetic neurons: past, present, and future perspectives. Neurochem Res 26: 875-889.

Jeyabalan A, Novak J, Danielson LA, Kerchner LJ, OPETT SL AND CONRAD KP. 2003. Essential role for vascular myogenic reactivity of small arteries. Circ Res 93: $1249-1257$.

Jeyabalan A, Novak J, Doty KD, Matthews J, Fisher MC, KERCHNER LJ AND CONRAD KP. 2007. Vascular matrix metalloproteinase-9 mediates the inhibition of myogenic reactivity in small arteries isolated from rats after short term administration of relaxin. Endocrinology 148: 189-197.

Jiang X, Dreano M, Buckler DR, Cheng S, Ythier A, Wu H, Hendrickson WA ANd El TAYAR N. 1995. Structural predictions for the ligand-binding region of glycoprotein hormone receptors and the nature of hormonereceptor interactions. Structure 3: 1341-1353.

Jockenhovel F, Altensell A And Nieschlag E. 1990. Active immunization with relaxin does not influence objectively determined sperm motility in rabbits. Andrologia 22: $171-178$.

JUDSON DG, PAY S AND BHOOLA KD. 1980. Modulation of cyclic AMP in isolated rat uterine tissue slices by porcine relaxin. J Endocrinol 87: 153-159.

Jurkiewicz NH, CARicati-Neto A, Verde LF, AVelLAR MCW, REUTER HR AND JURKIEWICZ A. 2006. Sympathetic neurotransmission in the rat testicular capsule: functional characterization and identification of mRNA encoding alpha1-adrenoceptor subtypes. Eur J Pharmacol 43: 141-150.

Kamat AA, Feng S, Bogatcheva NV, Truong A, Bishop CE And Agoulnik AI. 2004. Genetic targeting of relaxin and insulin-like factor 3 receptors in mice. Endocrinology 145: 4712-4720.

Karkanias GB, Ansonoff MA And Etgen AM. 1996. Estradiol regulation of alpha $1 \mathrm{~b}$-adrenoceptor mRNA in female rat hypothalamus-preoptic area. J Neuroendocrinol 8: 449-455.

Kern A, Agoulnik AI and Bryant-Greenwood GD. 2007. The low-density lipoprotein class A module of the relaxin receptor (leucine-rich repeat containing G-protein coupled receptor 7): its role in signalling and trafficking to the cell membrane. Endocrinology 148: 1181-1194.

KIM JK, KIM SJ, LEE JE, MIN KM AND KIM SJ. 2005. M3 subtype of muscarinic receptors mediate $\mathrm{Ca}^{2+}$ release from intracellular stores in rat prostate neuroendocrine cells. J Korean Med Sci 20: 256-261.

Kinghorn EM, BATE AS ANd Higgins SJ. 1987. Growth of rat seminal vesicle epithelial cells in culture: neurotransmitters are required for androgen-regulated synthesis of tissue-specific secretory proteins. Endocrinology 121: $1678-1688$. 
KOHSAKA T, TAKAhara H, SASAdA H, KAWARASAKI T, BAMBA K, Masaki J AND TAgami S. 1992. Evidence for immunoreactive relaxin in boar seminal vesicles using combined light and electron microscope immunocytochemistry. J Reprod Fertil 95: 397-408.

Kondo S, TAshima Y And Morita T. 1994. Segmental differences in the density of autonomic receptors in dog vas deferens. Urol Int 53: 62-67.

KrajnC-Franken MA, van Disseldorp AJ, KoEnders JE, Mosselman S, van Duin M And Gossen JA. 2004. Impaired nipple development and parturition in LGR7 knockout mice. Mol Cell Biol 24: 687-696.

Kubo T, Fukuda K, Mikami A, Maeda A, Takahashi H, Mishina M, Haga T, Haga K, IChiyama A And KANGAWA K. 1986. Cloning, sequencing and expression of complementary DNA encoding the muscarinic acetylcholine receptor. Nature 323: 411-416.

Kudo M, Chen T, NAKABAyashi K, Hsu SY AND HSUEH AJW. 2000. The nematode leucine-rich repeat-containing, $\mathrm{G}$ protein-coupled receptor LGR protein homologous to vertebrate gonadotropin and thyrotropin receptors is constitutively activated in mammalian cells. Mol Endocrinol 14: 272-284.

Lacey JP, Donatucci CF, Price DT, Page So, BenNETT SA, TENNISWOOD MP AND SCHWINN DA. 1996. Effects of androgen deprivation on prostate alpha 1-adrenergic receptors. Urology 48: 335-341.

LANGER S. 1999. History and nomenclature of alpha 1 adrenoceptors. Eur Urol 36: 2-6.

Lanzafame AA, Christopoulos A And Mitchelson F. 2003. Cellular signalling mechanism for muscarinic acetylcholine receptors. Receptor Channel 9: 241-260.

LAU WA AND PENnefather JN. 1998. Muscarinic receptor subtypes in the rat prostate gland. Eur J Pharmacol 343: $151-156$.

Laz TM, Forray C, Smith KE, BARd JA, VAysse PJ, BRANCHEK TA AND WEINSHANK RL. 1994. The rat homologue of the bovine alpha 1c-adrenergic receptor shows the pharmacological properties of the classical alpha 1A subtype. Mol Pharmacol 46: 414-422.

Leeb-Lundberg LM, Cotecchia S, Lomasney JW, DEBERnARdis JF, LEFKOWITZ RJ AND CARON MG. 1985. Phorbol esters promote alpha 1-adrenergic receptor phosphorylation and receptor uncoupling from inositol phospholipid metabolism. Proc Natl Acad Sci USA 82: 5651-5655.

LEFKOWITZ RJ. 1998. G protein-coupled receptors. III. New roles for receptor kinases and beta-arrestins in receptor signalling and desensitization. J Biol Chem 273: $18677-$ 18680.

LeFKowitz RJ AND CARON MG. 1988. Adrenergic receptors. Models for the study of receptors coupled to guanine nucleotide regulatory proteins. J Biol Chem 263: 49934996.

Lefkowitz RJ, Pitcher J, Krueger K AND DAAKA Y. 1998. Mechanisms of beta-adrenergic receptor desensitization and resensitization. Adv Pharmacol 42: 416-420.

Lenhart JA, Ryan PL, OHLETh KM, PALMER SS AND BAGNELL CA. 2001. Relaxin increases secretion of matrix metalloproteinase-2 and matrix metalloproteinase-9 during uterine and cervical growth and remodeling in the pig. Endocrinology 142: 3941-3949.

Lepor H, Zhang W, Kobayashi S, TANG R, Wang B AND SHAPIRO E. 1994. A comparison of the binding and functional properties of alpha-1 adrenoceptors and area density of smooth muscle in the human, canine and rat prostates. J Pharmacol Exp Ther 270: 722-727.

LEUng AYH, YIP WK AND Wong PYD. 1992. Characterization of adrenoceptors involved in the electrogenic chloride secretion by cultured rat epididymal epithelium. Br J Pharmacol 107: 146-151.

Liu C, Eriste E, Sutton S, Chen J, Roland B, Kuei C, FARMER N, JörnVAll H, Sillard R AND LOVENBERG TW. 2003. Identification of relaxin-3/INSL7 as an endogenous ligand for the orphan G-protein-coupled receptor GPCR135. J Biol Chem 278: 50754-50764.

Lockwood DH AND Williams-Ashman HG. 1971. Cholinergic-stimulated alkaline phosphatase secretion and phospholipid synthesis in guinea pig seminal vesicles. J Cell Physiol 77: 7-15.

LONGHURST PA AND BROTCKE TP. 1989. Effects of castration and diabetes mellitus on cholinergic responsiveness and muscarinic receptors in the rat vas deferens. J Urol 141: $1225-1229$.

Lopez-Gimenez JF, Canals M, Pediani JD And MilLIGAN G. 2007. The alphalb-adrenoceptor exists as a higher-order oligomer: effective oligomerization is required for receptor maturation, surface delivery, and function. Mol Pharmacol 71: 1015-1029.

Lucas TFG, Avellar MCW and Porto CS. 2004. Effects of carbachol on rat Sertoli cell proliferation and muscarinic acetylcholine receptors regulation: an in vitro study. Life Sci 75: 1761-1773.

Lucas TFG, Siu ER, Royer C, TRINDAde CS, NAder HB, LAZARI MFM AND PORTO CS. 2008. Muscarinic 
acetylcholine receptors: relevance to infertility and male contraception. Immun, Endoc \& Metab, Agents in Med Chem 8: 42-50.

Luthin GR, WANG P, Zhou H, Dhanasekaran D AND RUGGIERI MR. 1997. Role of $\mathrm{m} 1$ receptor-G protein coupling in cell proliferation in the prostate. Life Sci 60: 963-968.

MacDonald A AND MCGRath JC. 1980. The effects of castration on neurotransmission in the rat vas deferens. $\mathrm{Br}$ J Pharmacol 69: 49-58.

Mackenzie JF, Daly CJ, Pediani JD and McGrath JC. 2000. Quantitative imaging in live human cells reveals intracellular $\alpha_{1}$-adrenoceptor ligand-binding sites. J Pharmacol Exp Ther 294: 434-443.

MacKinnon AC, Spedding M And Brown CM. 1994. Alpha 2-adrenoceptors: more subtypes but fewer functional differences. Trends Pharmacol Sci 15: 119-123.

Mallard NJ, Marshall RW, Sithers AJ AND SPRIGGS TL. 1992. Separation of putative alpha 1Aand alpha $1 \mathrm{~B}$-adrenoceptor mediated components in the tension response of the rat vas deferens to electrical field stimulation. Br J Pharmacol 105: 727-731.

Manni L, Holmang A, Lundeberg T, Aloe L and STENER-Victorin E. 2005. Ovarian expression of alpha (1)- and beta (2)-adrenoceptors and p75 neurotrophin receptors in rats with steroid-induced polycystic ovaries. Auton Neurosci 118:79-87.

Manni L, Holmang A, Cajander S, Lundeberg T, Aloe L And Stener-Victorin E. 2006. Effect of anti-NGF on ovarian expression of alpha1- and beta2adrenoceptors, TrkA, p75NTR, and tyrosine hydroxylase in rats with steroid-induced polycystic ovaries. Am J Physiol Regul Integr Comp Physiol 290: R826-R835.

MARKus RP AND AVEllar MCW. 1997. Age-related changes in the reactivity of postsynaptic adrenoceptors in the rat vas deferens: differences between the epididymal and prostatic portion. Auton Pharmacol 17: 147-154.

Maróstica E, Guaze EF, Avellar MCW and Porto CS. 2001. Characterization of muscarinic acetylcholine receptors in rat epididymis. Biol Reprod 65: 1120-1126.

Maróstica E, Avellar MCW and Porto CS. 2005. Effects of testosterone on muscarinic acetylcholine receptors in the rat epididymis. Life Sci 77: 656-669.

McCune DF, Edelmann SE, Olges JR, Post GR, WalDrop BA, Waugh DJ, Perez DM and Piascik MT. 2000. Regulation of the cellular localization and signalling properties of the $\alpha_{1 \mathrm{~B}}$ - and $\alpha_{1 \mathrm{D}}$-adrenoceptors by agonists and inverse agonists. Mol Pharmacol 57: 659-666.
MCCUNE SK AND HiLl JM. 1995. Ontogenic expression of two alpha-1 adrenergic receptor subtypes in the rat brain. J Mol Neurosci 6: 51-62.

Mendes FR, Hamamura M, Queiróz DB, Porto CS AND AVELLAR MCW. 2004. Effects of androgen manipulation on alpha1-adrenoceptor subtypes in the rat seminal vesicle. Life Sci 75: 1449-1463.

Michelotti GA, Price DT and Schwinn DA. 2000. Alpha 1 adrenergic receptor regulation: basic science and clinical implications. Pharmacol Ther 88: 281-309.

Michelotti GA, BAuman MJ, SMith MP AND SCHWINN DA. 2003. Cloning and characterization of the rat alpha 1a-adrenergic receptor gene promoter. Demonstration of cell specificity and regulation by hypoxia. J Biol Chem 278: 8693-8705.

Miranda HF, Bustamante D, Castillo O, Salvatierra P, SaAvedra H, Fernandez E, Paeile C, PElissier T AND PinARdi G. 1992. Cholinergic receptors in the human vas deferens. J Recept Res 12: 101-115.

Miranda HF, Duran E, Bustamante D, Paeile C and PINARDI G. 1994. Pre- and postjunctional muscarinic receptor subtypes in the vas deferens of rat. Gen Pharmacol 25: $1643-1647$.

Miranda HF, Duran E, Fernandez E and Pinardi G. 1995. Muscarinic receptor subtypes in the bisected vas deferens of the rat. Gen Pharmac 26: 387-391.

MookerJee I, Unemori EN, Du XJ, Tregear GW AND SAMUEL CS. 2005. Relaxin modulates fibroblast function, collagen production and matrix metalloproteinase-2 expression by cardiac fibroblasts. Ann NY Acad Sci 1041: 190-193.

Moriyama N, Kurimoto S, Horie S, Nasu K, Tanaka T, Yano K, Hirano H, Tsujimoto G and Kawabe K. 1996. Detection of alpha 1-adrenoceptor subtypes in human hypertrophied prostate by in situ hybridization. Histochem J 28: 283-288.

Morrow AL AND CREeSE I. 1986. Characterization of alpha 1-adrenergic receptor subtypes in rat brain: a reevaluation of $\left[{ }^{3} \mathrm{H}\right] \mathrm{WB} 4104$ and $\left[{ }^{3} \mathrm{H}\right]$ prazosin binding. Mol Pharmacol 29: 321-330.

Muramatsu I, Oshita M, Ohmura T, Kigoshi S, AKino H, Gobara M And OKada K. 1994. Pharmacological characterization of $\alpha_{1}$-adrenoceptor subtypes in the human prostate: functional and binding studies. $\mathrm{Br}$ J Urol 74: 572-578.

Murray KT, Hu NN, DAW JR, Shin HG, WATSON MT, Mashburn AB AND GeOrge AL JR. 1997. Functional 
effects of protein kinase $\mathrm{C}$ activation on the human cardiac $\mathrm{Na}^{+}$channel. Circ Res 80: 370-376.

NADELHAFT I. 2003. Cholinergic axons in the rat prostate and neurons in the pelvic ganglion. Brain Res 989: 52-57.

NaKaoka H, Perez DM, BAeK KJ, DAs T, Husain A, Misono K, IM MJ AND GRAHAM RM. 1994. Gh: a GTP-binding protein with transglutaminase activity and receptor signalling function. Science 264: 1593-1596.

Nasu K, Moriyama N, Kawabe K, Tsujimoto G, Murai M, TANAKa T And Yano J. 1996. Quantification and distribution of $\alpha_{1}$-adrenoceptor subtype mRNAs in human prostate: comparison of benign hypertrophied tissue and non-hypertrophied tissue. Br J Pharmacol 119: 797-803.

Nasu K, Moriyama N, Fukasawa R, Tsujimoto G, TANAKA T, YANO J AND KAWABE K. 1998. Quantification and distribution of alpha1-adrenoceptor subtype $\mathrm{mR}$ NAs in human proximal urethra. Br J Pharmacol 123: $1289-1293$

NeWinger J, Jockenhovel F ANd Nieschlag E. 1990. The influence of relaxin on motility of human sperm in vitro. Andrologia 22: 335-339.

Nishi S, Hsu SY, Zell K And Hsueh AJW. 2000. Characterization of two fly LGR (Leucine-Rich Repeat-containing, $\mathrm{G}$ protein-coupled receptor) proteins homologous to vertebrate glycoprotein hormone receptors: constitutive activation of wild-type fly LGR1 but not LGR2 in transfected mammalian cells. Endocrinology 141: 4081-4090.

NOTHACKER HP AND GRIMMELIKHUIJZEN CJP. 1993. Molecular cloning of a novel putative $G$ protein-coupled receptor from sea anemones structurally related to members of the FSH, TSH, LH/CG receptor family from mammals. Biochem Biophys Res Commun 197: 1062-1069.

Obara K, Arai K, Miyajima N, Hatano A, Tomita Y AND TAKAHASHI K. 2000. Expression of m2 muscarinic acetylcholine receptor mRNA in primary culture of human prostate stromal cells. Urol Res 28: 196-200.

Papatsoris AG, Karamouzis MV and PapaVassiliou AG. 2007. The power and promise of "rewiring" the mitogen-activated protein kinase network in prostate cancer therapeutics. Mol Cancer Ther 6: 811-819.

PATrão MT, Queiróz DB, LÁzARi MF AND AVEllar MCW. 2008. Cloning, expression and immunolocalization of alpha1-adrenoceptor in different tissues from rhesus monkey and human male reproductive tract. Mol Hum Reprod 14: 85-96.

Pedretti A, Silva MA, Villa L and Vistoli G. 2004. Binding site analysis of full-length $\alpha_{1 \mathrm{a}}$ adrenergic receptor using homology modeling and molecular docking. Biochem Biophys Res Commun 319: 493-500.

PEREZ DM, PIASCIK MT, MALIK N, GAIVIN R AND GRAHAM RM. 1994. Identification of the mRNA for the novel alpha 1D-adrenoceptor and two other alpha 1adrenoceptors in vascular smooth muscle. Mol Pharmacol 46: $823-831$.

Petitti N, Karkanas GB And Etgen AM. 1992. Estradiol selectivity regulates alpha $1 \mathrm{~B}$-noradrenergic receptors in the hypothalamus and preoptic area. J Neurosci 12: 3869-3876.

PIASCIK MT AND PEREZ DM. 2001. Alpha1-adrenergic receptors: new insights and directions. J Pharmacol Exp Ther 298: 403-410.

Piascik MT, Guarino RD, Smith MS, Soltis EE, SAUSSY DL AND PEREZ DM. 1995. The specific contribution of the novel alpha-1D adrenoceptor to the contraction of vascular smooth muscle. J Pharmacol Exp Ther 275: 1583-1589.

Piascik MT, Hrometz SL, Edelmann SE, Guarino RD, HADLEY RW AND BROWN RD. 1997. Immunocytochemical localization of the alpha-1B adrenergic receptor and the contribution of this and the other subtypes to vascular smooth muscle contraction: analysis with selective ligands and antisense oligonucleotides. J Pharmacol Exp Ther 283: 854-868.

Pontari MA, LUthin GR, BraVerman AS AND RUGGIERI MR. 1998. Characterization of muscarinic cholinergic receptor subtypes in rat prostate. J Recept Signal Transduct Res 18: 151-166.

Porter JE, Hwa J And Perez DM. 1996. Activation of the alphalb-adrenergic receptor is initiated by disruption of an interhelical salt bridge constraint. J Biol Chem 271: 28318-28323.

Prenzel N, Zwick E, Daub H, Lesere M, Abraham R, Wallasch C AND UlRich A. 1999. EGF receptor transactivation by G-protein-couple receptors requires metalloproteinase cleavage of proHB-EGF. Nature 402: 884-888

Price DT, Chari RS, Berkowitz DE, MEyers WC AND SCHWINN DA. 1994a. Expression of alpha 1-adrenergic receptor subtype mRNA in rat tissues and human SK-NMC neuronal cells: implications for alpha 1-adrenergic receptor subtype classification. Mol Pharmacol 46: 221226.

Price DT, Lefkowitz RJ, CARon MG, Berkowitz D AND SCHWINN DA. 1994b. Localization of mRNA for 
three distinct alpha 1-adrenergic receptor subtypes in human tissues: implications for human alpha-adrenergic physiology. Mol Pharmacol 45: 171-175.

Price RR, MORRIS DP, BISWAS G, SMITH MP AND SCHWINN DA. 2002. Acute agonist-mediated desensitization of the human alpha 1a-adrenergic receptor is primarily independent of carboxyl terminus regulation: implications for regulation of alpha 1a-AR splice variants. J Biol Chem 277: 9570-9579.

PUPO AS. 1998. Functional effects of castration on $\alpha_{1-}$ adrenoceptors in rat vas deferens. Eur J Pharmacol 351: 217-223.

Pupo AS AND Minneman KP. 2003. Specific interactions between gClqR and alphal-adrenoceptor subtypes. J Recept Signal Transduct Res 23: 185-195.

Queiróz DB, Porto CS, Grossman G, Petrusz P AND AVELlar MCW. 2008. Immunolocalization of alpha(1A)-adrenoceptors in rat and human epididymis. Cell Tissue Res 332: 509-522.

Queiróz DBC, Mendes FR, Porto CS And Avellar MCW. 2002. Alpha1-adrenoceptor subtypes in rat epididymis and the effects of sexual maturation. Biol Reprod 66: 508-515.

QuesadA A And Etgen AM. 2002. Functional interactions between estrogen and insulin-like growth factor-1 in the regulation of alpha1B-adrenoceptors and female reproductive function. J Neuroscience 22: 2401-2408.

Ramarao CS, Denker JM, Perez DM, Gaivin RJ, RIEK RP AND GRAHAM RM. 1992. Genomic organization and expression of the human alpha $1 \mathrm{~B}$-adrenergic receptor. J Biol Chem 267: 21936-21945.

Ramsay D, CARr IC, Pediani J, Lopez-Gimenez JF, Thurlow R, Fidock M AND Milligan G. 2004. High-affinity interactions between human alpha1A-adrenoceptor C-terminal splice variants produce homo- and heterodimers but do not generate the alpha1L-adrenoceptor. Mol Pharmacol 66: 228-239.

RATNASOORIYA WD AND WADSWORTH RM. 1990. Impairment of fertility of male rats with prazosin. Contraception 41: 441-447.

RATNASOORIYA WD AND WADSWORTH RM. 1994. Tamsulosin, a selective $\alpha_{1}$ adrenoceptor antagonist, inhibits fertility of male rats. Andrologia 26: 107-110.

Rayford W, Noble MJ, Austenfeld MA, Weigel J, Mebust WK AND ShaH GV. 1997. Muscarinic cholinergic receptors promote growth of human prostate cancer cells. Prostate 30: 160-166.
Ricker DD, Chamness SL, Hinton BT AND CHANG TSK. 1996. Changes in luminal fluid protein composition in the rat cauda epididymidis following partial sympathetic denervation. J Androl 17: 117-126.

RoEhrborn CG AND Schwinn DA. 2004. Alpha-1 adrenergic receptors and their inhibitors in lower urinary tract symptoms and benign prostatic hyperplasia. J Urol 171: 1029-1035.

Rokosh DG, Bailey BA, Steward AFR, Karns LR, LONG CS AND SIMPSON PC. 1994. Distribution of $\alpha_{1 C}$ adrenergic receptor mRNA in adult rat tissues by RNase protection assay and comparison with $\alpha_{1 \mathrm{~B}}$ and $\alpha_{1 \mathrm{D}}$. Biochem Biophys Res Commun 200: 1177-1184.

Rokosh DG, Stewart AF, Chang KC, BAILEy BA, KARliner JS, CAMACHO SA, LONG CS AND SIMPSON PC. 1996. Alpha1-adrenergic receptor subtype mRNAs are differentially regulated by alpha1-adrenergic and other hypertrophic stimuli in cardiac myocytes in culture and in vivo. Repression of alpha1B and alpha1D but induction of alpha1C. J Biol Chem 271: 5839-5843.

Rudner XL, Berkowitz DE, Booth JV, Funk BL, Cozart KL, D'Amico EB, El-Moalem h, Page SO, Richardson CD AND Winters B. 1999. Subtype specific regulation of human vascular alpha(1)-adrenergic receptors by vessel bed and age. Circulation 100: 2336-2343.

RufFolo RR JR AND Hieble JP. 1999. Adrenoceptor pharmacology: urogenital applications. Eur Urol 36: 17-22.

Ruggieri MR, COLton MD, WANG P, SMYth RJ, PONTARI MA AND LUTHIN GR. 1995. Human prostate muscarinic receptor subtypes. J Pharmacol Exp Ther 274: 976-982.

Salamanca AE, Siemasko KF, Diebold Y, Calonge M, GAO J, JUÁreZ-CAMPo M AND STERN ME. 2005. Expression of muscarinic and adrenergic receptors in normal human conjunctival epithelium. Invest Ophthalmol Vis Sci 46: 504-513.

SAllÉs J AND BAdiA A. 1991. Mechanisms underlying the differential sensitivity to alpha 1-adrenoceptor activation in the bisected rat vas deferens. Br J Pharmacol 102: 439445.

SAmuel CS, Tian H, ZhaO L And Amento EP. 2003a. Relaxin is a key mediator of prostate growth and male reproductive tract development. Lab Invest 83: 10551067.

Samuel CS, Zhao C, Bathgate RA, Bond CP, Parry LJ, Summers RJ, TANG ML, AMENTO EP AND 
TREGEAR GW. 2003b. Relaxin deficiency in mice is associated with an age-related progression of pulmonary fibrosis. FASEB J 17: 121-123.

Samuel CS, Zhao C, Bathgate RAD, Du XJ, SumMERs RJ, Amento EP, WALKer LL, MCBurnie M, ZHAO L AND TREgEAR GW. 2005. The relaxin geneknockout mouse: a model of progressive fibrosis. Ann NY Acad Sci 1041: 173-181.

Sanbe A, Tanaka Y, Fujiwara Y, Tsumura H, YaMaUchi J, Cotecchia S, KoIKe K, Tsujimoto G AND TANOUE A. 2007. Alpha-1 adrenoceptor is required for normal male sexual function. Br J Pharmacol 52: 332340.

SANBorn BM, KuO HS, WeIsbrodt NW AND SHERWOOD OD. 1980. The interaction of relaxin with the rat uterus. I. Effect on cyclic nucleotide levels and spontaneous contractile activity. Endocrinology 106: 12101215.

Sarosi P, Schoenfeld C, Berman J, BASCH R, RANdolph G, Amelar R, Dubin L, Steinetz BG and WEISS G. 1983. Effect of anti-relaxin antiserum on sperm motility in vitro. Endocrinology 112: 1860-1861.

Sato T, BAN Y, UCHida M, Gondo E, Yamamoto M, SeKiguchi Y, SAKaue A, Kemi M And NaKatsuka T. 2005. Atropine-induced inhibition of sperm and semen transport impairs fertility in male rats. J Toxicol Sci 30: 207-212.

SAussy DL JR, Goetz AS, QueEn KL, King HK, Lutz MW AND RIMELE TJ. 1996. Struture activity relationships of a series of buspirone analogs at alpha-1 adrenoceptors: further evidence that rat aorta alpha-1 adrenoceptors are of the alpha-1D-subtype. J Pharmacol Exp Ther 278: 136-144.

SAWUtz DG, LANiER SM, WARrEn CD AND GRAHAM RM. 1987. Glycosylation of the mammalian alpha 1adrenergic receptor by complex type $\mathrm{N}$-linked oligosaccharides. Mol Pharmacol 32: 565-571.

ScArparo AC, Sumida DH, Patrão MTCC, AVEllar MCW, Visconti MA AND CASTRUCCi MA. 2004. Catecholamine effects on human melanoma cells evoked by alpha1-adrenoceptors. Arch Dermatol Res 296: 112119.

SCHWINN DA AND KWATRA MM. 1998. Expression and regulation of alpha 1-adrenergic receptors in human tissues. Adv Pharmacol 42: 390-394.

SCHWinn DA, LOMASNEY JW, LOREnZ W, SzKLUt PJ, FREMEAU RT, YANG-FENG TL, CARON MG, LEFKOWITZ RJ AND COTECCHIA S. 1990. Molecular cloning and expression of the cDNA for a novel alpha 1-adrenergic receptor subtype. J Biol Chem 265: 8183-8189.

SCOFIELd MA, LiU F, ABEL PW AND JEFFries WB. 1995. Quantification of steady state expression of mRNA for alpha-1 adrenergic receptor subtypes using reverse transcription and a competitive polymerase chain reaction. $\mathrm{J}$ Pharmacol Exp Ther 275: 1035-1042.

Scott DJ, LAYField S, ReisewiJk A, Morita $\mathrm{H}$, Tregear GW AND BAthgate RAD. 2005. Characterisation of the mouse and rat relaxin receptors. Ann NY Acad Sci 1041: 8-12.

ScotT DJ, LAYField S, YAN Y, Sudo S, Hsueh AJ, Tregear GW and Bathgate RA. 2006. Characterization of novel splice variants of LGR7 and LGR8 reveals that receptor signalling is mediated by their unique low density lipoprotein class A modules. J Biol Chem 281: 34942-34954.

ShanNON HE, SAWYer BD, BEmis KG, ByMASTER FP, Health I, Mitch CH and Ward JS. 1993. Muscarinic M1 receptor agonist actions of muscarinic receptor agonists in rabbit vas deferens. Eur J Pharmacol 232: $47-57$.

Shapiro E, Miller AR And Lepor H. 1985. Downregulation of the muscarinic cholinergic receptor of the rat prostate following castration. J Urol 134: 179-182.

Shen H, Peri KG, Deng XF, Chemtob S And Varma DR. 2000. Distribution of $\alpha_{1}$-adrenoceptor subtype proteins in different tissues of neonatal and adult rats. Can J Physiol Pharmacol 78: 237-243.

SHERWOOD OD. 2004. Relaxin's physiological roles and other diverse actions. Endocrine Rev 25: 205-234.

SHIMA S. 1992. Effects of androgen on $\alpha$-and $\beta$-adrenergic receptors in membranes from the rat seminal vesicle. Biochim Biophys Acta 1175: 123-127.

Shinoura H, Shibata K, Hirasawa A, Tanoue A, Hashimoto K And Tsujimoto G. 2002. Key amino acids for differential coupling of alpha1-adrenergic receptor subtypes to Gs. Biochem Biophys Res Comm 299: 142-147.

Silva MA, Megale A, Avellar MCW and Porto CS. 1999. Expression and pharmacological characterization of $\alpha_{1}$-adrenoceptors in rat seminal vesicle. Eur J Pharmacol 381: 141-149.

Siu ER, Yasuhara F, Maróstica E, Avellar MCW AND PORTO CS. 2006. Expression and localization of muscarinic acetylcholine receptor subtypes in the rat efferent ductules and epididymis. Cell Tissue Res 323: $157-166$. 
SKINNER MK. 2005. Sertoli cell secreted regulatory factors. In: SKINNER MK AND GRISWOLD MD (Eds), Sertoli Cell Biology, Elsevier Science, San Diego, USA, p. 107-120.

Sokol RZ, WANG XS, LECHAGo J, JOHNSTON PD AND SWERDLOFF RS. 1989. Immunohistochemical localization of relaxin in human prostate. J Histochem 37: 12531255.

Steinetz BG, Schwabe C, Callard IP And GoldSMITH LT. 1998. Dogfish shark (Squalus acanthias) testes contain a relaxin. J Androl 19: 110-115.

Sudo S, Kumagai J, Nishi S, Layfield S, Ferraro T, BAthgate RA AND Hsueh AJ. 2003. H3 relaxin is a specific ligand for LGR7 and activates the receptor by interacting with both the ectodomain and the exoloop 2 . J Biol Chem 278: 7855-7862.

Sugawara T, Hirasawa A, Hashimoto K and TsujiMOTO G. 2002. Differences in the subcellular localization of alpha1-adrenoceptor subtypes can affect the subtype selectivity of drugs in a study with the fluorescent ligand BODIPY FL-prazosin. Life Sci 70: 2113-2124.

Suzuki F, TANiguchi T, TAKauji R, Murata S AND MURAN I. 2000. Splice isoforms of $\alpha_{1 \mathrm{a}}$ adrenoceptor in rabbit. Br J Pharmacol 129: 1569-1576.

TAyebati SK, Bronzetti E, Morra Di Cella S, Mulatero P, Ricci A, Rossodivita i, Schena M, Schiavone D, Veglio F And Amenta F. 2000. In situ hybridization and immunocytochemistry of $\alpha_{1}$ adrenoceptors in human peripheral blood lymphocytes. J Auton Pharmacol 20: 305-312.

Teng CM, Guh JH And Ko FN. 1994. Functional identification of alpha 1-adrenoceptor subtypes in human prostate: comparison with those in rat vas deferens and spleen. Eur J Pharmacol 265: 61-66.

Tensen CP, Van Kesteren ER, Planta RJ, Cox KJ, Burke JF, VAN HEERIKHUIZEN H AND VREUGDENHIL E. 1994. A G protein-coupled receptor with low density lipoprotein-binding motifs suggests a role for lipoproteins in G-linked signal transduction. Proc Natl Acad Sci USA 91: 4816-4820.

Testa R, Guarneri L, Taddei C, Poggesi E, Angelico P, Sartani A, Leonardi A, Gofrit ON, Meretyk S AND CAINE M. 1996. Functional antagonistic activity of Rec 15/2739, a novel alpha-1 antagonist selective for the lower urinary tract, on noradrenaline-induced contraction of human prostate and mesenteric artery. J Pharmacol Exp Ther 277: 1237-1246.
Thebault S, Zholos A, Enfissi A, Slomianny G, DeWAilly E, RoudbaraKi M, PARYS J AND PREVARsKAYA N. 2005. Receptor-operated $\mathrm{Ca}^{2+}$ entry mediated by TRPC3/TRPC6 proteins in rat prostate smooth muscle (PS1) cell line. J Cell Physiol 204: 320-328.

Theroux TL, Esbenshade TA, PeAvy RD And MinneMAN KP. 1996. Coupling efficiencies of human alpha 1adrenergic receptor subtypes: titration of receptor density and responsiveness with inducible and repressible expression vectors. Mol Pharmacol 50: 1376-1387.

Toews ML, Prinster SC And Schulte NA. 2003. Regulation of alpha-1B adrenergic receptor localization, trafficking, function, and stability. Life Sci 74: 379-389.

Uberti MA, Hall RA And Minneman KP. 2003. Subtype-specific dimerization of alpha 1-adrenoceptors: effects on receptor expression and pharmacological properties. Mol Pharmacol 64: 1379-1390.

Uberti MA, Hague C, Oller H, Minneman KP AND HALL RA. 2005. Heterodimerization with beta2-adrenergic receptors promotes surface expression and functional activity of alpha1D-adrenergic receptors. J Pharmacol Exp Ther 313: 16-23.

VAN DiJK MM, DE LA Rosette JJ AND Michel MC. 2006. Effects of alpha(1)-adrenoceptor antagonists on male sexual function. Drugs 66: 287-301.

VAN Koppen CJ AND KAISER B. 2003. Regulation of muscarinic acetylcholine receptor signalling. Pharmacol Ther 98: $197-220$.

VARma DR And Deng XF. 2000. Cardiovascular alpha 1 adrenoceptor subtypes: functions and signalling. Can J Physiol Pharmacol 78: 267-292.

VÁzQuez-Prado J, Medina LC, Romero-Avila MT, GonZALEZ-EspinosA C AND GARCIA-SAINZ JA. 2000. Norepinephrine- and phorbol ester-induced phosphorylation of alpha(1a)-adrenergic receptors. Functional aspects. J Biol Chem 275: 6553-6559.

Ventura S, Pennefather J And Mitchelson F. 2002. Cholinergic innervation and function in the prostate gland. Pharmacol Ther 94: 93-112.

Vicentic A, Robeva A, Rogge G, Uberti M And MinNEMAN KP. 2002. Biochemistry and pharmacology of epitope-tagged $\alpha_{1}$-adrenergic receptor subtypes. J Pharmacol Exp Ther 302: 58-65.

Vivas NM, Giraldo J, Tabernero A, Vila E AND BADIA A. 1997. Use of the operational model of agonism and $\left[{ }^{3} \mathrm{H}\right]$ prazosin binding to assess altered responsiveness of alpha1-adrenoceptors in the vas deferens of 
spontaneously hypertensive rat. Naunyn Schmiedebergs Arch Pharmacol 356: 383-391.

WALDEN PD, GERARDi C AND LEPOR H. 1999. Localization and expression of the $\alpha_{1 \mathrm{~A}-1}, \alpha_{1 \mathrm{~B}}$ and $\alpha_{1 \mathrm{D}}$-adrenoceptors in hyperplastic and non-hyperplastic human prostate. J Urol 161: 635-640.

WALKer WH AND Cheng J. 2005. FSH and testosterone signalling in Sertoli cells. Reproduction 130: 15-28.

Wang JM, McKenna KE And LeE C. 1991. Determination of prostatic secretion in rats: effect of neurotransmitters and testosterone. Prostate 18: 289-301.

WANG X ET AL. 2005. Spinophilin regulates $\mathrm{Ca}^{2+}$ signalling by binding the N-terminal domain of RGS 2 and the third intracellular loop of G-protein-coupled receptors. Nat Cell Biol 7: 405-411.

Waugh DJ, Zhao MM, Zuscik MJ and Perez DM. 2000. Novel aromatic residues in transmembrane domains IV and $\mathrm{V}$ involved in agonist binding at alpha(1a)-adrenergic receptors. J Biol Chem 275: 11698-11705.

WESS J. 2004. Muscarinic acetylcholine receptor knockout mice: novel phenotypes and clinical implications. Annu Rev Pharmaco Toxicol 44: 423-450.

WIER WG AND MORGAN KG. 2003. Alpha1-adrenergic signalling mechanisms in contraction of resistance arteries. Rev Phys Biochem Pharmacol 150: 91-139.

XIAO L AND JEFFrIES WB. 1998. Kinetics of alkylation of cloned rat alpha1-adrenoceptor subtypes by chloroethylclonidine. Eur J Pharmacol 347: 319-327.

Xu Z, Hirasawa A, Shinoura H and Tsujimoto G. 1999. Interaction of the alpha(1B)-adrenergic receptor with gC1q-R, a multifunctional protein. J Biol Chem 274: 21149-21154.

YAN HH, Mruk DD, LeE WM AND Cheng CY. 2007. Ectoplasmic specialization: a friend or a foe of spermatogenesis? Bioessays 29: 36-48.

YANG M, VERFÜRTH F, BÜSCHER R AND MiCHEL MC. 1997. Is alpha1D-adrenoceptor protein detectable in rat tissues? Naunyn Schmiedebergs Arch Pharmacol 355: $438-446$

YAng-Feng TL, Xue Fy, Zhong WW, Cotecchia S, Frielle T, CARON MG, LEFKOWITZ RJ AND FRANCKE U. 1990. Chromosomal organization of adrenergic receptor genes. Proc Natl Acad Sci USA 87: 1516-1520.
YANG-FENG TL, HAN H, LOMASNEY JW AND CARON MG. 1994. Localization of the cDNA for an alpha 1adrenergic receptor subtype (ADRA1D) to chromosome band 20p13. Cytogenet Cell Genet 66: 170-171.

YAsuoka A, ABe K, Arai S And EMori Y. 1996. Molecular cloning and functional expression of the alpha1Aadrenoceptor of Medaka fish, Oryzias latipes. Eur J Biochem 235: 501-507.

YAZAWA H AND HoNDA K. 1993. Alpha 1-adrenoceptor subtype in the rat prostate is preferentially the alpha $1 \mathrm{~A}$ type. Jpn J Pharmacol 62: 297-304.

YAZAWA H, SAITA Y, IIDA E, HoNMA Y, MORITA T AND HONDA K. 1994. Characterization of muscarinic cholinoceptor in primary culture of smooth muscle cells from human prostate. J Urol 152: 2173-2177.

YKi-JARVINEN H, WAHLSTROM T AND SePpala M. 1983. Immunohistochemical demonstration of relaxin in the genital tract of men. J Reprod Fertil 69: 693-695.

Yoshinaga T, Zhang S, NiIdome T, HiraOKa M AND HiRANA Y. 1999. Potentiation of recombinant L-type Ca channel currents by alpha1-adrenoceptors coexpressed in baby hamster kidney (BHK) cells. Life Sci 64: 16431651.

Zhao L, Roche PJ, Gunnersen JM, Hammond VE, Tregear GW, Wintour EM and Beck F. 1999. Mice without a functional relaxin gene are unable to deliver milk to their pups. Endocrinology 140: 445-453.

ZHONG H AND MinNEMAN K. 1999. alpha 1 adrenoceptor subtypes. Eur J Pharmacol 375: 261-276.

Zhong H, LeE D, Robeva A And Minneman KP. 2001. Signalling pathways activated by alphal-adrenergic receptor subtypes in PC12 cells. Life Sci 68: 2269-2276.

ZIMMERMANN S, STEDING G, EMMEN JM, BRINKMANN AO, Nayernia K, Hostein AF, Engel W AND ADHAM IM. 1999. Targeted disruption of the INsl3 gene causes bilateral cryptorchidism. Mol Endocrinol 13: 681-691.

Zuscik MJ, Piascik MT and Perez DM. 1999. Cloning, cell-type specificity, and regulatory function of the mouse alpha(1B)-adrenergic receptor promoter. Mol Pharmacol 56: 1288-1297. 